\title{
Badenian (middle Miocene) continental paleoenvironment in the Novohrad-Nógrád Basin (Central Paratethys): a volcano-sedimentary record from the Páris-patak Valley in Hungary
}

\author{
BORDY, M. Emese ${ }^{1, *} \&$ SzTANó, Orsolya ${ }^{2}$ \\ 'Department of Geological Sciences, University of Cape Town, Private Bag X3, Rondebosch, 7701, Cape Town, South Africa, emese.bordy@ uct.ac.za, \\ http://orcid.org/0000-0003-4699-0823 \\ ²Department of Geology, Eötvös Loránd University, Pázmány Péter sétány 1/c, Budapest, 1117, Hungary, orsolya.sztano@ @tk.elte.hu, \\ http://orcid.org/0000-0003-0786-3653 \\ *- corresponding author
}
Badeni (középsó miocén) folyóvízi öskörnyezet a Palócföldön: vulkáni-üledékes rétegsorok a Páris-patak völgyéból

Összefoglalás

A késő badeniben képződött andezit piroklaszt összletbe két szintben is konglomerátumból, homokkőből és agyagkövekből álló vulkanoklasztos rétegsor települ a Páris-patak völgyében és a környező völgyekben Nógrádszakáltól északra, a magyar-szlovák határ közelében. A vizsgált képződmények a Közép-Szlovákiai neogén vulkáni mező peremén rakódtak le. A vulkanoklasztos üledékek szállítási mechizmusa és képződési környezete pontos meghatározása érdekében terepi szedimentológiai elemzéseket végeztünk, ennek során megfigyeltük a vulkanoklasztos rétegek fácieseit, többek közt oldalirányú és függőleges szemcseméret-változásokat, üledékszerkezeteket, szöveti és összetételbeli változásokat, valamint a fáciesegyüttesek geometriáját és összefogazódásait. A kovásan cementált vulkanoklasztos rétegek szemcséi uralkodóan andezitek, kb. 5\% klasztot túzkő, kvarcit, gránit, csillámpala, gneisz, tufa (lapillikô) és szenesedett fadarabok alkotnak. A szemcseméret a nagyobb hömpölyöktől a durva kavicson, a nagy- és középszemú homokon át az agyagos kőzetlisztig terjed. A durvaszemcsés fáciesegyüttesbe vastag, durván rétegzett, táblás geometriájú vagy néhány méter széles lencse alakú, főleg szemcsevázú konglomerátumok tartoznak, melyek talpa erozív, s melyben a szemcsék középső (b) tengelye szerinti zsindelyesség gyakori. Ugyancsak előfordulnak az előzőekkel váltakozó kavicsból felépülő táblás keresztrétegzettségú kötegek is. A finomszemcsés fáciesegyüttest keresztrétegzett, kavicsos homokkő és tufitos, agyagos aleurolitlencsék alkotják. Emellett ritkábban, de a homokban előfordulnak sík- és keresztlemezesség, vízkiszökési szerkezetek is. Mindkét együttesben találunk feltépett agyagklasztokat, melyek legnagyobb átmerője az 1 métert is eléri, jelezve, hogy a rétegsorban legalább ilyen vastag pelitrétegek, felhagyott mederkitöltések is lehettek az üledékképződéssel egy időben. A fáciesegyüttesek több helyen és rétegtani szintben éles eróziós talpú, 0,5-4 m vastag, felfelé csökkenő szemcseméretú rétegsorokat alkotnak. Ezek sekély, folyásirányban és kissé oldalirányban épüló hosszanti zátonyokkal feltöltött mederkitöltések, kiterjedt, lapos kavicstakarók és zátonyok üledékei, melyek mozgása áradások legnagyobb sebességú szakaszaihoz köthető. A szemcsék zsindelyessége, a keresztrétegzések dőlésiránya és a kövült fatörzsek irányítottsága jelzi az egykori szállítási irányokat. Az üledék görgetett fenékhordalékként szállítódott $\sim \mathrm{D}$, a felső szintben $\sim \mathrm{Ny}$ felé. Időnként törmelékfolyások is megjelentek. A medrekben mozgó, kisebb keresztrétegzett homoktestek a kis/közepes vízhozamú időszakokban jöttek létre. A szemcseméret változékonysága a vízhozamok gyakori ingadozására utal, a növényi és egyéb gerinces maradványokat is figyelembe véve egy alapvetôen nedves éghajlatú időszakban. A területen 4-5 méter mély, közepes méretú, kis kanyargósságú medrek rekonstruálhatóak, melyek a Lysec paleovulkán DK-i peremterületén egy kavicsos, fonatos folyó üledékes rendszerét alkották. A benne felhalmozódó vulkanoklasztos üledék a kitörések közötti nyugalmi időszakokban, leginkább csapadékos éghajlaton a korábban lerakódott piroklasztok átülepítéséből származhat.

Kulcsszavak: késó badeni, ôskörnyezet, fonatos folyó, fácieselemzés, zsindelyesség, szállitási irány, Novohrad-Nógrád Geopark, Lysec

Abstract

Two levels of volcaniclastics, comprising conglomerates, sandstones and mudstones, are interbedded with upper middle Miocene (upper Badenian) andesite pyroclastics near the Hungarian-Slovakian border in the distal region of the Central Slovakian Neogene Volcanic Field. Based on the field sedimentological investigations, the facies of the volcaniclastics (e.g., lateral and vertical grain size changes, sedimentary structures, textures, clast composition), their geometry and field relationships are documented herein with the aim of reconstructing the depositional environment. The silica-cemented volcaniclastics are mostly andesite clasts with only $\sim 5 \%$ being granitoid, quarzitic, and tuff clasts as well 
as charred fossil wood fragments. The coarse-grained facies association includes crudely stratified, tabular or lenticular, clast-supported pebble-cobble conglomerates with erosive basal surfaces, b-axis imbrication, alternating with sets of cross bedding. The fine-grained facies association comprises cross-bedded pebbly to medium-grained sandstone and lenses of tuffaceous clayey siltstone with rare horizontal lamination and water-escape structures. Rip-up mudstone clasts, with diametre up to $1 \mathrm{~m}$, are present in both facies associations, revealing the co-existence of abandoned silty palaeochannel plugs. Facies associations are arranged in several 0.5-4-m-thick, fining-upwards successions that likely formed in shallow channels as downstream to laterally accreting longitudinal bars, extensive gravel sheets and bars that migrated in peak flow during floods. Palaeocurrent indicators (i.e., clast imbrication, direction of planar cross-bedding, orientation of petrified wood logs) show bedload transport by traction currents, initially towards $\sim \mathrm{S}$, and later towards $\sim \mathrm{W}$. Intermittently debris flows also occurred. Cross-bedded sandstones formed as in-channel transverse bars during medium/low discharge. Variation of grain size shows frequent discharge fluctuations during permanently wet conditions in the late Badenian. The 4-5-m-deep, low-sinuosity channels were part of a high-energy, gravel-bed braided-river system on the south-eastern foothills of the Lysec palaeovolcano. Here, pyroclastics were reworked and redeposited as volcaniclastics during inter-eruption, high-discharge episodes.

Keywords: late Badenian, palaeoenvironment, braided river, facies analysis, clast imbrication, palaeocurrents, Novohrad-Nógrád Geopark, Lysec

\section{Introduction}

The upper Badenian (middle Serravallian) volcaniclastic rock succession outcropping north of the village of Nógrádszakál (Hungary) is an epitome of the adage that goes: "geology does not follow political boundaries". This is because, at least in part, the geological makeup in the area, which lies immediately east of the Hungarian-Slovakian border, conforms to that in the Central Slovakian Neogene Volcanic Field (e.g., CHERnyshev et al. 2013; Figure 1A, B). The upper middle Miocene near Nógrádszakál comprise primarily of pyroclastic andesitic units that are interbedded with subordinate volcaniclastics that range from conglomerates, sandstones and mudstones. The volcaniclastics are exposed in the picturesque Páris-patak Valley, also dubbed as the "Palóc Grand Canyon", which has been well-known among tourists for decades. The interest in the geological history of the area has grown significantly since the establishment of the Novohrad-Nógrád Geopark in the 2010 (https://www.nogradgeopark.eu/en/novohrad-nogradgeopark). Although the unique lithological characters and mappable nature of the volcaniclastics $\mathrm{N}$ of Nógrádszakál has been recognized by HÁMOR (1997), the palaeoenvironmental setting of these volcaniclastics is debated in the Hungarian geological literature, with some authors suggesting a coastal marine (e.g. HÁMOR 1985, TUBA 1985), while others proposing a fully continental, alluvial setting of deposition (e.g., NosZKY 1923; BogSCH 1942; BARTKÓ 1952; KoRdOS-SZAKÁLY 1984a, b). This study focuses on the field sedimentological investigations pertaining to the genesis of the upper Badenian volcaniclastic rocks exposed in the Páris-patak and neighbouring valleys, north of Nógrádszakál (Figure 1).

\section{Geological background}

Separated by the gorge of the Ipoly/Ipel' River, the hilly, forested area $\mathrm{N}$ of Nógrádszakál (Figure 1) is the geomorphological and geological continuation of the southern Slovakian mountains (e.g., GAÁl 1905, BoGSCH 1942, NoSZKY et al. 1952, BARTKÓ 1952, BALOGH et al. 1966). The nearest peak is that of the Lysec palaeo-volcano (Figure 1A), the K-Ar radioisotopic dating of which gave a late Badenian age of 13.05 $\pm 0.51 \mathrm{Ma}$ (PÉCSKAY 2012). This age is corroborated by the biostratigraphy of the underlying marine successions in southern Slovakia (e.g., VASS et al. 2005, KovÁč et al. 2017, HudÁČKOVÁ et al. 2020). Forming part of the Central Slovakian Neogene Volcanic Field (e.g., CHERnYSHEV et al. 2013; Figure 1A), the intense eruptions of andesitic volcanic material in the Lysec area produced pyroclastics and interbedded volcaniclastics that were deposited initially in nearshore marine and then in essentially continental settings as the Badenian shoreline was displaced southward (e.g., KonEČNÝ et al. 1995, VASS 2002, KonEČNÝ \& LEXA 2002, PÉCSKAY 2012, MANDIC et al. 2019, HudÁČKOvÁ et al. 2020, LEXA et al. 2010). This upper Badenian volcaniclastic succession is termed the Lysec Formation in Slovakia (e.g., KONEČNÝ et al. 1983, VASS 2002, KONEČNÝ \& LEXA 2002, HudÁČKOVÁ et al. 2020), however across the Hungarian border, $\mathrm{N}$ of Nógrádszakál, the same rocks have been mapped as part of the Nagyhársas Andesite (e.g., Prakfalvi 2012,

$\rightarrow$ Figure 1. Location, stratigraphy and sedimentology of the study area

A) Position of the study area within Central Europe and within the middle Miocene regional palaeogeography (modified after ZeLENKA et al. 2004, Kováč et al. 2017). B) Simplified geological map of the study area (KUN-JÁGER 1997). Legend same as in C) Base map from Kartográfiai Vállalat 2001, original scale 1:10 000. For the Slovakian geological map, see https://apl.geology.sk/gm50js. C) Geological cross-sections showing the spatial relationship of the two volcaniclastic levels to the other main stratigraphic units in the study area. For location, see B. D) Simplified geological log of the Nógrádszakál-2 deep structural borehole (BH Nsz-2). Adapted from HámOR (1985). E) Generalized sedimentary facies log of the two volcaniclastic levels in the study area. Note that the lower level is finer compared to the upper level. For facies codes, see Table I

$\rightarrow$ 1. ábra. A vizsgált terület elhelyezkedése, rétegtani és szedimentológiai felépitése

A) A kutatási terület földrajzi és középsö miocén ösföldrajzi helyzete (ZELENKA et al. 2004, KoVáč et al. 2017 alapján). B) Egyszerüsített földtani térkép (KUN-JÁGER 1997) melynek alapja a Kartográfiai Vállalat 2001, 1:10 000 térképe, jelkulcsa C)-vel egyezö. A felhasznált szlovák földtani térkép elérhetö https://apl.geology.sk/gm50js. C) Földtani szelvények mutatják a két vulkanoklasztos szint és a többi képzödmény rétegtani viszonyait. A szelvények nyomvonala a B) ábrán. D) A Nógrádszakál-2 (Nsz-2) szerkezetkutató fúrás által feltárt egyszerüsített rétegsor, HÁmoR (1985) alapján. E) A vulkanoklasztos összlet általános üledékes rétegoszlopa, melyen megfigyelhetö, hogy az alsó összlet szemcsemérete valamivel kisebb a felsöénél. Részletes magyarázat a szövegben és a kódokat összegzö I. táblázatban 


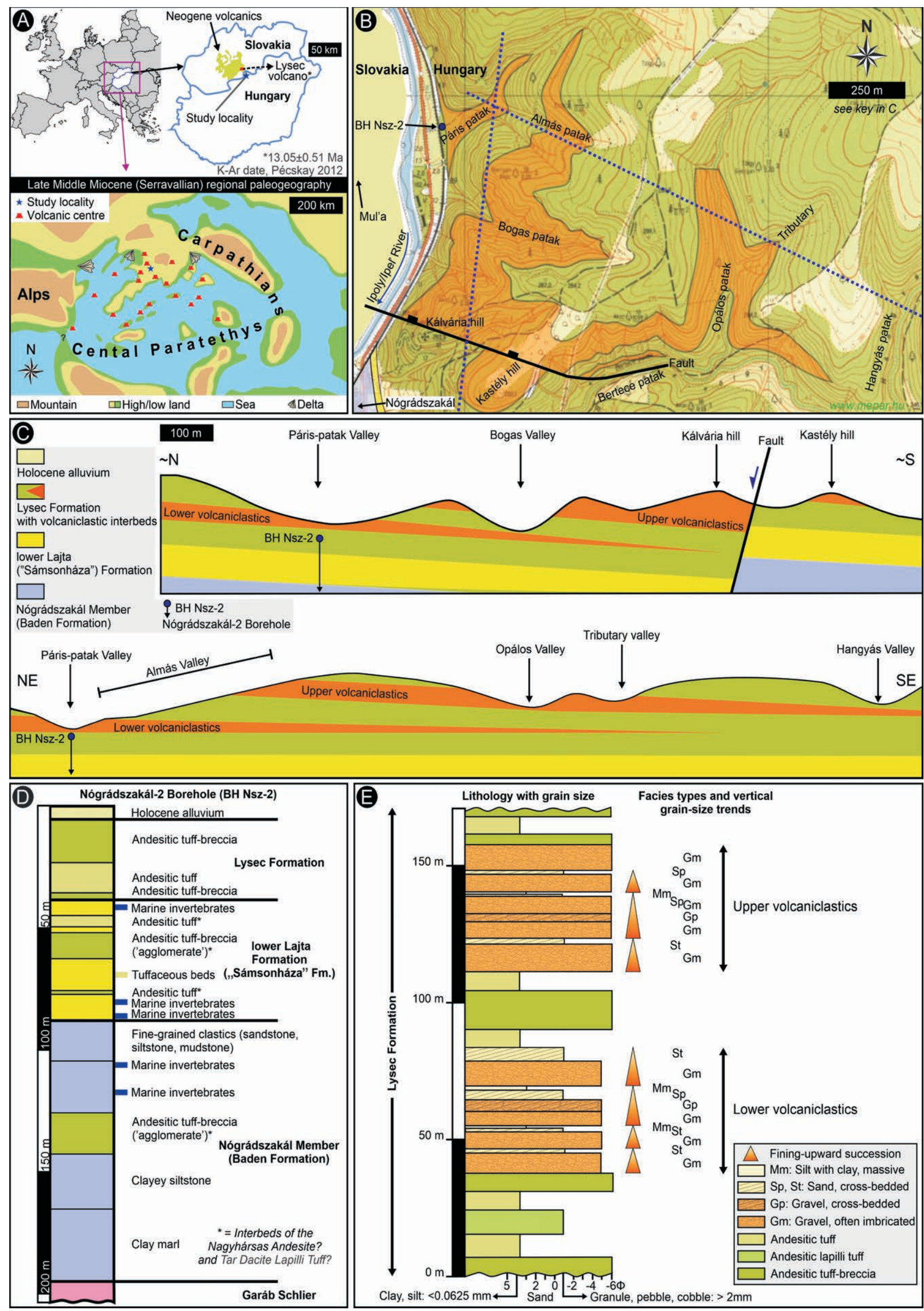


VENCZEL \& HíR 2015), as well as part of the upper Lajta Formation (e.g., HÁMOR 1985, PRAKFALVI 2012). The former is part of the Mátra-Cserhát Volcanic Complex in northern Hungary, which in addition to the main igneous rock units, it also contains marine volcanogenics (e.g., KARÁTSON et al. 2001, Di CAPUA et al. 2021). Based on $\mathrm{K}-\mathrm{Ar}$ radioisotopic dating, it appears to be 14.5-16.3 Ma old (ZELENKA 2010, KERCSMÁR et al. 2015), and thus slightly older than the Lysec volcanics. In addition to the direct lithostratigraphic correspondence with the Lysec Formation (see KUN-JÁGER 1997 for details), the late Badenian age of the andesitic volcaniclastic succession $\mathrm{N}$ of Nógrádszakál is also supported by the biostratigraphy of the unconformably underlying lower to middle Badenian and older rocks (e.g., lower Lajta Limestone Formation, Nógrádszakál Marl Member of the Baden Formation and Garáb Schlier Formation; Figure 1D) that were extensively investigated in the vicinity of the study area in boreholes and surface exposures (e.g., HÁMOR 1985, Hír 2013, VENCZEL \& Hír 2015, Hír et al. 2016). The fossil assemblages in these older rocks are not only age diagnostic but also show the predominantly shallow marine origin of these underlying rocks. In contrast to this, the fossils from the volcaniclastic rock record near the Paris-patak Valley, both from the pyroclastics and volcaniclastics, indicate a predominantly continental origin. Except for rare, reworked, isolated sponge spicules, unidentified shark and batoid teeth that exclusively occur in the oldest volcaniclastic layers, all other fossils in Paris-patak Valley and environs (Figure 1B) are remains of unequivocally terrestrial or freshwater organisms (e.g., GAÁL 1905, TuBA 1985, Hír 1993). These fossils include diverse late Badenian plants (e.g., Ginkgo, Tetraclinis, Equisetum, Parrotia, Populus, Ulmus, Salix, Alnus, Ostrya, Pterocarya, palms and other evergreen species) suggesting gallery-forest as well as riparian conditions in proximity of water (KORDOSSZAKÁLY 1984a, b) as well as animals ranging from microvertebrates (frogs, snakes; Hír 1993) to various megaherbivores. The latter fauna comprises the mandibles with molars of a rhinocerotid (Aceratherium? or Hoploaceratherium? tetradactylum? GAÁL 1905, VARGA 1994, GASPARIK M. pers. comm. 2020), a molar of a mammutid proboscidean (Zygolophodon turicensis; SCHLESINGER 1922; GASPARIK 2001, 2004) and a molar of an odd-toed ungulate (Chalicotherium grande; HíR 1993). While the vertebrate fossils were collected from the volcaniclastics (e.g., Hír 1993), the abovelisted plant fossils originate from the pyroclastics (e.g., KoRDOS-SZAKÁLY 1984a). Because of the foregoing and based our primary mapping both in Hungary and Slovakia (see KuNJÁGER 1997), the studied succession is regarded as part of the Lysec Formation herein.

\section{Material and methods}

The upper Badenian volcaniclastic succession outcropping $\mathrm{N}$ of Nógrádszakál, in Páris-patak Valley (GPS $48^{\circ} 11^{\prime} 40.73$ ”N, $19^{\circ} 31^{\prime} 49.04$ 'E) and environs, and in particular its volcaniclastics (chiefly andesitic conglomerates, sandstones, mudstones) were geologically mapped at metrescale (Figure $1 B, C$ ). The extent of the overall study region is $\sim 1.5 \mathrm{~km}^{2}$ (Figure $1 B$ ) in heavily forested area, where the vegetation cover is high all year around, and thus fair-quality exposures are found mainly in incised stream valleys and rarely in hillside sections. The primary data was collected in 1997, and in our recent revisit of the site noted that some of the outcrops have been destroyed or significantly changed due to natural weathering and/or depositional processes. The studied stratigraphic interval is a maximum 200-m-thick volcanosedimentary succession, which extends from the basal pyroclastics (e.g., andesitic tuff-breccias ('agglomerates'), andesitic tuffs, andesitic lapilli tuffs sensu LE MAITRE et al. 2002) into the volcaniclastics that occur in two mappable stratigraphic levels (Figure 1B, C, D).

This study uses the mature, standard method of qualitative lithofacies classification and analysis based on works by Miall (1978a, 1985, 1988, 1996, 2016). In this standard field sedimentological modus operandi, the key sedimentary facies properties of the volcaniclastics, including but not limited to lateral and vertical grain size changes, sedimentary structures, textures, clast composition, as well as the geometry and field relationships of the facies, were documented in field sketches, photographs and representative centimetre-scale sedimentary facies logs. For the qualitative assessment of the sedimentary facies architecture, the fair-quality (but rarely 3-dimensional) exposures of the volcaniclastics were turned into outcrop lithofacies maps, which illustrate on field-drawn outcrop sketches, the spatial distribution of the lithofacies and outline the key sedimentological surfaces in each outcrop. The presence of carbonates was tested regularly with $10 \%$ dilute hydrochloric acid. To reconstruct the sediment supply direction (see methods in e.g., High \& PiCARD 1974, Miall 1974, DASGUPTA 2002) in the studied stratigraphic interval, a total of 417 palaeocurrent indicators were measured that included clast imbrication (400 data points), planar cross-bedding (10 data points) and petrified wood log orientation ( 7 data points). Clast imbrication was measured in batches of 25 clasts within one given layer and always on the intermediate (b) axis of clasts as this was the only imbrication direction in them. In case of the fossil wood logs, the strike of their long (a) axis was recorded.

\section{Results}

\section{General characteristics}

The 100-150-m-thick volcaniclastic succession N of Nógrádszakál contains volcaniclastics in two distinct stratigraphic levels (Figure 1B, C, E). The Paris-patak Valley only exposes the lower volcaniclastic level, whereas its tributaries, the Almás and Bogas Valleys, expose both volcaniclastic levels (Figure $1 B, C$ ). Fair-quality exposures of the upper volcaniclastic level are also found in the Opal Valley and its tributary (Figure $1 B, C$ ). The grain size in both volcaniclastic levels range from very coarse pebbles and cobbles to clayey silts (Figures 1D, 2), with the maximum clast size being 0.8-1 $\mathrm{m}$ (the largest clasts are always made up of andesites). Relative 


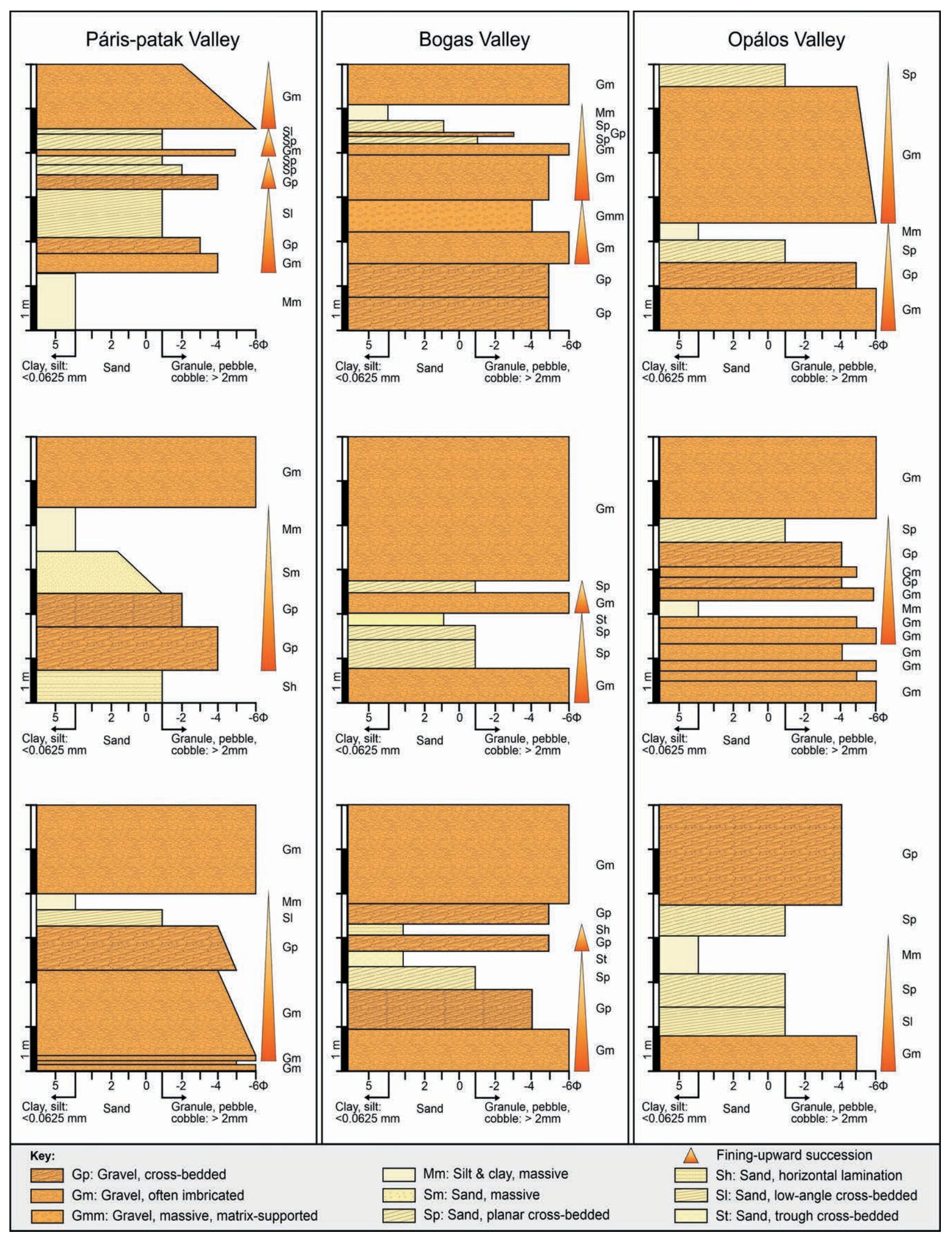

Figure 2. Representative centimetre-scale sedimentary facies logs from the lower (Páris-patak Valley) and upper (Bogas and Opálos Valleys) volcaniclastic level For location of the valleys, see Figure 1. For facies codes, see Table I

2. ábra. Jellegzetes centiméter-léptékü felvételen alapuló üledékes rétegoszlopok az alsó (Páris-patak völgye) és a felsö (Bogas-és Opálos-völgy) vulkanoklasztos szintböl A völgyek helyszinnrajza az 1. ábrán. Részletes magyarázat a szövegben és a kódokat összegzó I. táblázatban 
to the upper level, the abundance of the sandstones is higher and the average clast size in the conglomerates is about two times smaller (average diametre: $4-5 \mathrm{~cm}$ ) in the lower volcaniclastic level (Figure 1D). All layers show limited lateral continuity of a few metres only and no individual layer can be traced across adjacent outcrops irrespective of their proximity to each other. Therefore, the centimetre-scale sedimentary facies logs (Figure 2), which were measured in the same volcaniclastic level within a given valley (e.g., Páris-patak Valley or Bogas Valley) cannot be correlated to each other. The sedimentary logs also show that the volcaniclastic levels comprise several, fining-upwards successions that range in thickness from $\sim 0.5$ to $\sim 4 \mathrm{~m}$ (average thickness $\sim 2 \mathrm{~m}$; Figure 2). These successions commence with an erosive, often irregular basal surface that underlies the coarse-grade member in each of the successions. The grain size of the fine-grade member is variable from very coarse, pebbly sand to clayey silt, without an apparent relationship to the thickness of the fining-upwards succession.

\section{Clast composition}

The clasts are up to $95 \%$ andesites with variable texture, the most common being aphanitic. Other clast types, which are 6-7 $\mathrm{cm}$ in size on average, include quartz, chert, quartzite (3$4 \%)$ as well as rare granite, mica schist, gneiss and tuff (1-2\%). In each valley, granite cobbles and up to $50-\mathrm{cm}$-diametre boulders are rare but present. Up to $90 \%$ of andesite clasts are well or very well rounded, non-spherical and less commonly moderately spherical. The non-volcanic clasts are rounded, and moderately spherical. The quarzitic clasts are smooth (without chatter marks) but poorly rounded and non-spherical. Tuff clasts are always poorly rounded. All conglomerate clasts across the study area are either moderately or poorly sorted; well-sorted clast populations are absent, hence, the conglomerates are submature both texturally and compositionally. Among the quarzitic clasts, rounded petrified fossil wood fragments, which are 4-10 cm in length and black in colour, are also common. Moreover, in both volcaniclastic levels, fossil wood fragments with a blackened outer crust (either charred or coalified) are common; they are typically $20-40 \mathrm{~cm}$ long and 5-30 $\mathrm{cm}$ in diametre.

In the sandstones and the matrix of the conglomerates, the sand-size fraction is medium- to coarse-grained and predominantly andesitic in composition. The quartz sand content is maximum $15-20 \%$. The mud-size particle content, which was shown to be mostly montmorillonite by TuBA (1985), can be very high, especially in the finegrained rock types (e.g., clayey siltstones). All rocks types are assumed to be silica cemented, because field-based $10 \%$ dilute hydrochloric acid testing did not detect carbonates.

\section{Palaeocurrents}

Orientation data from measured palaeocurrent indicators (i.e., dip direction of imbricated clasts' intermediate axis, foresets in planar cross-bedding and strike direction of the long axis in petrified wood log) is shown in conventional rose diagrams in Figure 3. It is worth noting that the petrified wood log data in the Páris-patak Valley is from a cross-bedded conglomerate layer in which the foresets dip direction is perpendicular to the strike of the logs' long axis. This is important, because it suggests that the wood logs were likely transported perpendicular to the flow direction, possibly as bedload, rolling around their long axis. This would be in contrast to the transport mode, for example, in debris flows, where wood logs often (but not exclusively see MuIR et al. 2015 and references therein) get transported with their long axis aligned parallel to the flow direction. As illustrated in the rose diagrams and associated data table in Figure 3, the consistency of all palaeocurrent data groups is high and the data is unidirectional. These are parameters in line with low sinuosity fluvial channels typical in braided rivers or braided alluvial fans (e.g., RUST 1972, 1978; RUST \& Koster 1984; Steel \& Thomson 1983). The palaeocurrent direction in the planar cross-bedding and wood logs (both taken in the Páris-patak Valley) are from the lower volcaniclastic level and suggest a flow direction from $\sim \mathrm{N}$ to $\sim$ S (Figure 3A, 3B). All 400 clast imbrication data are from the upper volcaniclastic level and suggest a flow direction approximately from $\sim$ E to $\sim \mathrm{W}$ (Figure $3 D$ ).

\section{Facies classification and description}

Based on the standard method of qualitative lithofacies classification (Table I), the volcaniclastic sedimentary rocks in the study area can be grouped into the following two main facies associations:

(1) Coarse-grained facies association of conglomerates, which accounts for more than $90 \%$ of the rock types in the study area (e.g., Figures 2, 4, 5);

(2) Fine-grained facies association of sandstones and subordinate clayey siltstones (e.g., Figures 2, 6, 7, 8), which shows a higher abundance only locally, mostly in the lower volcaniclastic level, especially in the Páris-patak Valley, where it accounts for $20 \%$ of the rock types (Figures 1D, 2).

The coarse-grained facies association is dominated by conglomerates (Table I) that typically occur in tabular, sheet-like beds that can be traced laterally for up to $10 \mathrm{~m}$, across most of the outcrops, which are typically narrow $(<10 \mathrm{~m}$ wide; Figures $4 A, 5 C, 8 A, 8 C$ ). It is possible that these beds are more continuous laterally, given that within a given exposure, the beds maintain a fairly uniform thickness. The tabular conglomerates are thus mostly bound by erosion surfaces that are fairly even at the base (Figures $4 A, 7 C, 8 A$, $8 C$ ) and slightly downward dipping at the top, however gently undulating basal erosion surfaces also occur (e.g., Figure $4 F$, $4 G, 6 A$ ). Lenticular conglomerates are less common (Figures $4,5 C, 5 D, 6 A$ ), and typically occur as $0.5-2 \mathrm{~m}$ thick and $3-8 \mathrm{~m}$ wides units. Within the lenses, the grain-size often decreases laterally and vertically (Figure 5).

The most common facies type in the study area is the massive to faintly bedded, clast-supported conglomerate (facies $\mathrm{Gm}$ ) that ranges in thickness from 0.5 to $3 \mathrm{~m}$ 

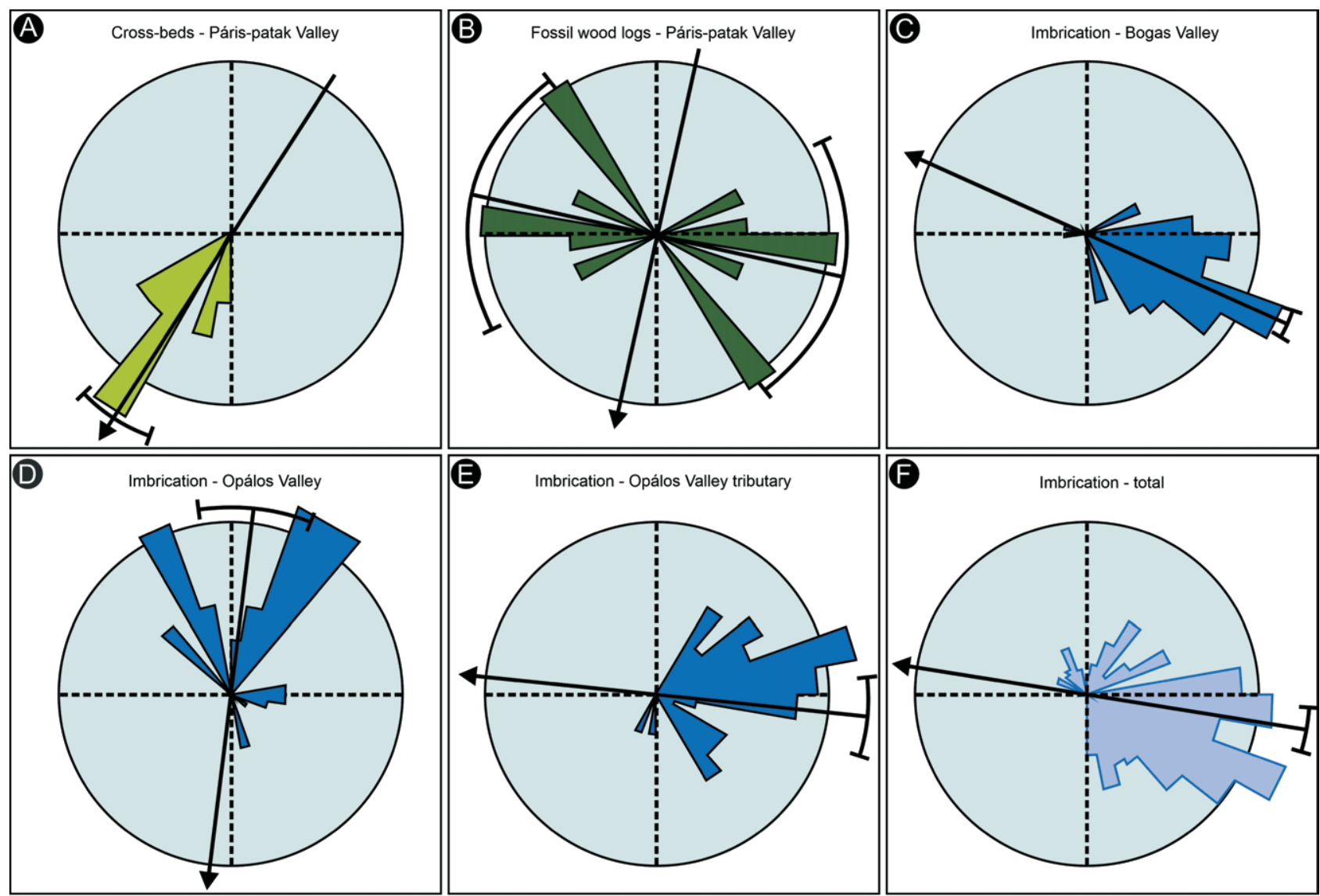

\begin{tabular}{|c|c|c|c|c|c|c|}
\hline Data collection field sites & $\begin{array}{c}\text { A- Cross- } \\
\text { beds in Páris- } \\
\text { patak Valley }\end{array}$ & $\begin{array}{c}\text { B-Fossil } \\
\text { wood logs } \\
\text { (strike) in } \\
\text { Páris-patak Valley }\end{array}$ & $\begin{array}{c}\text { C- } \\
\text { Imbrication in } \\
\text { Bogas Valley }\end{array}$ & $\begin{array}{c}\text { D - } \\
\text { Imbrication in } \\
\text { Opálos Valley }\end{array}$ & $\begin{array}{c}\text { E-Opálos } \\
\text { Valley } \\
\text { tributary }\end{array}$ & $\begin{array}{c}\text { F-All } \\
\text { imbrication } \\
\text { data }\end{array}$ \\
\hline Population & 10 & 7 & 225 & 100 & 75 & 400 \\
\hline Maximum percentage & 30 & 28.6 & 17.3 & 11 & 13.3 & 10.5 \\
\hline Mean percentage & 20 & 20 & 7.1 & 3.7 & 5.3 & 3.2 \\
\hline Standard deviation in \% & 7.07 & 7.38 & 4.82 & 2.93 & 3.31 & 2.95 \\
\hline Vector mean (degree) & 312.88 & 283.59 & $113.93(+180)$ & $6.9(+180)$ & $95.81(+180)$ & $98.98(+180)$ \\
\hline Confidence interval (degree) & 10.16 & 42.68 & 3.77 & 15.47 & 10.89 & 5.87 \\
\hline Magnitude of resultant vector & 0.96 & 0.62 & 0.88 & 0.48 & 0.7 & 0.6 \\
\hline
\end{tabular}

Figure 3. Rose diagrams based on palaeocurrent indicators from the study area

A-B are cross-bed and wood log data from the lower volcaniclastic level, whereas C-F are clast imbrication in facies Gm from the upper volcaniclastic level. Note the different main palaeocurrent direction in the lower vs. upper levels. For statistical details of each dataset, see summary table. For location of the valleys, see Figure 1

3. ábra. Az üledékszerkezetekben mért szállitási irányok (nyilak) rózsadiagramokon

A) keresztrétegzés és B) fatörzsek orientációja alapján az alsó vulkanoklasztos szintböl, és C-F) Gm fáciesü rétegek klasztjainak zsindelyességéból a felső vulkanoklasztos szintben. Az alsó és a felső szint szállitási irányai közt jelentös eltérés mutatkozik. A statisztikai adatok a táblázatban, a mérések helye az 1. ábrán látható

(Figures 2, 4-8). The most common and striking feature of facies $\mathrm{Gm}$ is clast imbrication (Figure $4 A, 4 B$ ) that is particularly prominent around larger, very coarse pebbles and cobbles. Imbrication is exclusively along the clasts' intermediate axis. Within a given facies Gm layer, upwards and lateral grain size decrease is present, but not too common (Figures 2, 5B, 5C, 5D). Nesting mostly within facies $\mathrm{Gm}$ and rarely occurring as individual beds, localised patches of matrix-supported conglomerates also occur (facies Gmm; e.g., Figures 2, 5B). Although facies
Gmm is rare in the Páris-patak Valley, it is common in the other outcrop areas.

Cross-bedded conglomerates (especially facies Gp, less so $\mathrm{Gt}$ ) are the second most common rock types in the study area (Figures 2, 4D, 4E, 4G, 4H, 5, 6C). They occur in thinner (average $0.5 \mathrm{~m}$ ) beds compared to those of facies $\mathrm{Gm}$. Lateral and upward reduction in clast size within individual gravel foresets is common (Figures $4 \mathrm{D}, 4 \mathrm{H}, 7 \mathrm{~A}$ ). It is noteworthy that the upward reduction in clast size in $>1$ m-thick beds (Figure 2) likely resulted from the amal- 
Table I. Fluvial lithofacies descriptions and interpretations (modified after MiALL 1978a, 1985, 1996) from the studied stratigraphic interval N of Nógrádszakál. Also see Figures 2-8 for the sedimentary facies logs and the facies relationships in the field. Note that the facies codes are indicated on the close-up images and sketches of the outcrops

I. táblázat. A folyóviz összletekre használatos litofáciesek leirása és értelmezése (MIALL 1978a, 1985, 1996 alapján) a vizsgált, Nógrádszakáltól északra kibukkanó rétegsorban. V.ö. az üledékes rétegoszlopokkal és a fáciesek kapcsolatát bemutató panorámaszelvényekkel, közelképekkel (2-8. ábrák), ahol a fáciesek kódja segíti azok azonositását

\begin{tabular}{|c|c|c|c|}
\hline $\begin{array}{c}\text { Facies } \\
\text { code } \\
\text { Fáciesek } \\
\text { kódja }\end{array}$ & $\begin{array}{c}\text { Facies shown in figure } \\
\text { Fáciesek ábraanyaga }\end{array}$ & $\begin{array}{l}\text { Description } \\
\text { Leirás }\end{array}$ & $\begin{array}{l}\text { Interpretation } \\
\text { Értelmezés }\end{array}$ \\
\hline Gm & $\begin{array}{l}4 \mathrm{~A}-\mathrm{D}, 4 \mathrm{~F}-\mathrm{H} \\
5 \mathrm{~B}-\mathrm{D}, 6 \mathrm{~A} \\
6 \mathrm{C}-\mathrm{D}, 7 \mathrm{~A}, 7 \mathrm{C} \\
\quad 8 \mathrm{~A}-\mathrm{C}\end{array}$ & $\begin{array}{l}\text { Gravel, clast-supported, massive or slightly } \\
\text { bedded. Imbrication very common. Upward and } \\
\text { lateral clast size decrease occurs. Forms the } \\
\text { coarse member in upwards-fining successions. } \\
\text { Contains clayey siltstone rip-up, fossilized } \\
\text { wood, andesite, and other rare non-andesitic } \\
\text { clasts types. The most common facies. } \\
\text { Szemcsevázú, szerkezetmentes vagy durván } \\
\text { rétegzett kavics. Egymást követö rétegek, lencsék } \\
\text { többnyire csökkenö szemnagyságúak, a } \\
\text { zsindelyesség nagyon gyakori. Feltépett agyagos- } \\
\text { aleurolitklasztok, szénült fadarabok, andezit és } \\
\text { más ritka exotikus anyagú szemcsék alkotják. Ez } \\
\text { a leggyakoribb fácies. }\end{array}$ & $\begin{array}{l}\text { Forms as longitudinal bedforms in channels, possibly } \\
\text { during high magnitude discharge events. Horizontal } \\
\text { bedding indicates sustained flow. Roundness of non- } \\
\text { andesitic clasts may indicate long travel distances or high } \\
\text { energy grinding action in traction currents. } \\
\text { Hosszanti rétegformaként épül medrekben valószinüleg nagy } \\
\text { víz- és üledékhozamú események (árvizek) alkalmával }\end{array}$ \\
\hline Gmm & $4 D, 5 B$ & $\begin{array}{l}\text { Gravel, matrix-supported, massive. Rare } \\
\text { facies. } \\
\text { Mátrixvázú, szerkezetmentes kavics. } \\
\text { Ritkán jelenik meg }\end{array}$ & $\begin{array}{l}\text { Forms from plastic debris flow during bank collapse, } \\
\text { due to renewed channel flow strength. Lack of } \\
\text { structures can mean rapid reduction in flow speed and/or } \\
\text { sudden sediment overloading and/or "sieve" deposits } \\
\text { Törmelékfolyásból rakódik le, melyet megnövekedett } \\
\text { áramlásintenzitás kiváltotta partomlás vagy extrém } \\
\text { csapadékesemény okoz. A szerkezetek hiányát hirtelen } \\
\text { sebességcsökkenés, gyors lerakódás vagy a kisebb szemesék } \\
\text { utólagos beszürödése a nagyok közti pórustérbe okozhatja. }\end{array}$ \\
\hline Gp & $\begin{array}{l}4 \mathrm{C}-\mathrm{D}, 1 \mathrm{E} \\
4 \mathrm{G}-\mathrm{H}, 5 \mathrm{~A}-\mathrm{D} \\
6 \mathrm{C}-\mathrm{D}, 7 \mathrm{~A}-\mathrm{C} \\
\quad 8 \mathrm{~B}-\mathrm{C}\end{array}$ & $\begin{array}{l}\text { Gravel, clast-supported, mostly planar, rarely } \\
\text { trough cross-bedded. } \\
\text { Szemcsevázú, általában táblásan, ritkán vályúsan } \\
\text { keresztrétegzett kavics }\end{array}$ & $\begin{array}{l}\text { Forms as down-current migrating gravel bars in open } \\
\text { channels. } \\
\text { Kavicszátonyok folyásirányú vándorlásával épül nyilt } \\
\text { medrekben. }\end{array}$ \\
\hline Sm & $4 \mathrm{H}, 6 \mathrm{C}, 7 \mathrm{~A}, 7 \mathrm{C}$ & $\begin{array}{l}\text { Sand, mostly coarse-grained, occasionally } \\
\text { medium-grained, with pebbles, massive. Often } \\
\text { contains wood fragments. Rare facies. } \\
\text { Szerkezetmentes, kavicsos, föleg nagy-, kisebb } \\
\text { részben középszemcsés homok. Gyakoriak a } \\
\text { fadarabok benne. Ritka fáciestípus. }\end{array}$ & $\begin{array}{l}\text { Forms due to mass movements (hyperconcentrated or } \\
\text { debris flows) in floods or bank collapse. Alternatively, } \\
\text { primary structures destroyed by recent weathering or } \\
\text { bioturbation or dewatering as pore water escapes and } \\
\text { deforms soft sediment (occurs during fast rates of } \\
\text { sedimentation). } \\
\text { Aradásokhoz kapcsolódó tömegmozgás (hipersürü ár) vagy } \\
\text { partomlás üledéke. Az sem kizárt, hogy az elsödleges } \\
\text { szerkezetet, az ülepedést követö bioturbáció vagy a } \\
\text { pórusfolyadék hirtelen távozása (likvidizációja) tüntette el. } \\
\text { Utóbbi gyors üledékfelhalmozódást jelez. Végsö soron a } \\
\text { jelenkori felszínközeli mállási folyamatok is felülírhatják. }\end{array}$ \\
\hline Sh & $4 \mathrm{D}, 5 \mathrm{~B}, 5 \mathrm{D}, 6 \mathrm{C}$ & $\begin{array}{l}\text { Sand, mostly medium-grained, horizontal } \\
\text { lamination. Very rare facies. } \\
\text { Síklemezes, középszemcsés homok. Nagyon ritka } \\
\text { fáciestípus. }\end{array}$ & $\begin{array}{l}\text { Forms as plane bedforms in upper flow conditions in } \\
\text { shallow water depths. } \\
\text { Szuperkritikus (sebes) áramlási tartománybam, azaz gyorsan } \\
\text { áramló, nagyon sekély vizben képzödö rétegforma. }\end{array}$ \\
\hline SI & $4 \mathrm{C}, 6 \mathrm{D}, 7 \mathrm{~A}, 8 \mathrm{~A}$ & $\begin{array}{l}\text { Sand, mostly coarse-grained, occasionally } \\
\text { medium-grained; low-angle cross-bedding } \\
\text { (foreset dip angle }<10^{\circ} \text { ). Rare facies. } \\
\text { Kis szögü keresztrétegzés (dölése }<10^{\circ} \text { ) föleg } \\
\text { nagy-, kisebb részben középszemcsés homokban. } \\
\text { Ritka fáciestípus. }\end{array}$ & $\begin{array}{l}\text { Forms as barforms, scour fills, humpback or washed-out } \\
\text { dunes, antidunes. } \\
\text { Lapos zátonyforma, mélyedéskitöltés vagy sebesbe váltó } \\
\text { áramlással formált, eltéritett düne szerkezete. }\end{array}$ \\
\hline St & $\begin{array}{c}4 \mathrm{~F}, 4 \mathrm{H}, 5 \mathrm{D} \\
6 \mathrm{C}-\mathrm{D}, 7 \mathrm{~A}\end{array}$ & $\begin{array}{l}\text { Sand, mostly coarse-grained, occasionally } \\
\text { medium-grained; trough cross-bedding. Rare } \\
\text { facies. } \\
\text { Vályús keresztrétegzés föleg nagy-, kisebb részben } \\
\text { középszemcsés homokban. Ritka fáciestípus. }\end{array}$ & $\begin{array}{l}\text { Forms as down-current migrating sinuous-crested dunes } \\
\text { in higher flow velocities than } \mathrm{Sp} \text {. } \\
\text { Folyásirányban vándorló, hajladozó gerincü dünék szerkezete, } \\
\text { mely csendes áramlási tartományban, de az egyenes gerincü } \\
\text { dünékhez képest nagyobb sebességü áramlás esetén jön létre. }\end{array}$ \\
\hline
\end{tabular}


Table I continuation

I. táblázat folytatása

\begin{tabular}{|c|c|c|c|}
\hline $\begin{array}{c}\text { Facies } \\
\text { code } \\
\text { Fáciesek } \\
\text { kódja }\end{array}$ & $\begin{array}{c}\text { Facies shown in figure } \\
\text { Fáciesek ábraanyaga }\end{array}$ & $\begin{array}{l}\text { Description } \\
\text { Leirás }\end{array}$ & $\begin{array}{l}\text { Interpretation } \\
\text { Értelmezés }\end{array}$ \\
\hline Sp & $\begin{array}{l}1 \mathrm{C}, 1 \mathrm{E}-\mathrm{H}, 5 \mathrm{~A}- \\
\mathrm{B}, 5 \mathrm{D}, 6 \mathrm{~A}-\mathrm{D} \\
7 \mathrm{~A}-\mathrm{C}, 8 \mathrm{~A}, 8 \mathrm{C}\end{array}$ & $\begin{array}{l}\text { Sand, mostly coarse-grained, occasionally } \\
\text { medium-grained; planar cross-bedding. May } \\
\text { contain wood fragments and charred wood } \\
\text { debris. The most common sandstone facies. } \\
\text { Táblás keresztrétegzés föleg nagy-, kisebb részben } \\
\text { középszemesés homokban.Tartalmazhat } \\
\text { fadarabokat és szénült fatörmeléket. A } \\
\text { legyakoribb homokfácies. }\end{array}$ & $\begin{array}{l}\text { Forms as down-current migrating straight-crested dunes } \\
\text { (transverse bedforms) in more moderate flow regimes than } \\
\text { St. } \\
\text { Folyásirányban vándorló, egyenes gerincü dünék, } \\
\text { keresztzátonyok szerkezete, mely csendes áramlási } \\
\text { tartományban, de a hajladozó gerincü dünékhez képest } \\
\text { kisebb áramlási sebesség esetén jön létre. }\end{array}$ \\
\hline $\mathrm{Sr}$ & - & $\begin{array}{l}\text { Sand, fine-grained; ripple cross-lamination. } \\
\text { Extremely rare facies. } \\
\text { Keresztlemezes-aprószemcsés homok. Nagyon } \\
\text { ritka fácies. }\end{array}$ & $\begin{array}{l}\text { Forms from the migration of ripples in a low flow } \\
\text { regime. } \\
\text { Csendes áramlási tartományban mozgó áramlásfodrok } \\
\text { szerkezete. }\end{array}$ \\
\hline Mm & $5 \mathrm{~B}, 7 \mathrm{~A}, 8 \mathrm{~A}-\mathrm{C}$ & $\begin{array}{l}\text { Silt-size fines, massive or rarely faintly } \\
\text { laminated. Plant fossils are common. Lacks } \\
\text { visible bioturbation structures. Desiccation } \\
\text { cracks in one outcrop. Rare facies. } \\
\text { Szerkezetmentes vagy ritkán lemezes aleurolit, } \\
\text { növénymaradványokkal, lenyomatokkal. Látható } \\
\text { bioturbáció nélkül. Egy feltárásában száradási } \\
\text { repedésekkel. Ritka fácies. }\end{array}$ & $\begin{array}{l}\text { Forms from suspension settling in waning floods in } \\
\text { abandoned channels or overbank areas. Absence of } \\
\text { laminations likely indicates quick deposition (e.g., } \\
\text { mudflows) rather than pervasive bioturbation. Subaerial } \\
\text { exposure of wet sediment caused drying and cracking. } \\
\text { Allóvizben lebegtetett hordalékból ülepedik árvizek után } \\
\text { felhagyott medrekben vagy gáton túli ártéren. A lemezesség } \\
\text { hiánya valószínüleg gyors ülepedést (pl. iszapfolyások) jelez, } \\
\text { esetleg átható bioturbációt. A nedves pélitek szárazulati } \\
\text { kitettsége kiszáradáshoz, felcserepesedéshez vezethet. }\end{array}$ \\
\hline
\end{tabular}

Facies codes: $\mathrm{G}=$ Gravel, $\mathrm{S}=$ Sand, $\mathrm{M}$ = mud, $\mathrm{t}=$ trough cross-bedding, $\mathrm{p}=$ planar cross-bedding, $\mathrm{h}$ = horizontal lamination, $\mathrm{m}=$ massive/matrix-supported (context dependent), 1 = lowangle, $\mathrm{r}=$ ripple.

Fácieskódok: $G=$ kavics, $S=$ homok, $M=$ agyag, aleurit, $t=$ vályús keresztrétegzés, $p=$ táblás keresztrétegzés, $h=$ síklemezesség, $m=$ szerkezetmentes vagy mártixvázú (helyzettöl függöen), $l=$ kis szögü, $r=$ áramlás fodor.

gamation of several bedforms that lacked clear bedding planes. Moreover, intercalation of gravel foresets with coarser and finer clasts (with the latter often being sandy) is also present (Figure $4 D, 4 E, 4 H$ ). Locally, the forests are tangential to the basal erosional bounding surface of the beds (Figure $4 H$ ). Foreset inclination is 20-30 degrees (i.e., in Figures $4 D, 4 H, 5 B$ inclinations in $\mathrm{Gp}$ is vertically exaggerated).

The fine-grained facies association is dominated by coarse-grained and less commonly medium-grained, often pebbly sandstones (e.g., Figures $4 E, 4 H, 5 D, 6 B$ ) and clayey siltstones (facies Mm; Table I, Figures 2, 4-8). It usually forms $<1 \mathrm{~m}$ thick (maximum $\sim 2.3 \mathrm{~m}$ ), either tabular or more commonly lenticular beds especially in the upper member of fining-upwards successions (Figures 2, 5-8). It may also occur as isolated, shallow lenses within facies Gm (Figure $4 F$ ) and at the contact of facies $\mathrm{Gm}$ and Gp (Figure $4 H$ ). Planar cross-bedding (facies $\mathrm{Sp}$ ) is by far the most common facies type in the sandstones, however trough cross-bedding (facies St), low-angle cross-bedding (Sl), horizonal lamination (facies $\mathrm{Sh}$ ) and massive sandstones (facies $\mathrm{Sm}$ ) also occur (Figures 2, 4-8). Facies Sm is dominant in association with water-escape structures (Figure 7) as well as with petrified fossil wood fragments and rip-up siltstone clasts (Figure 5B). Ripple cross-laminated sandstones (facies $\mathrm{Sr}$ ) are exceptionally rare.

In facies $\mathrm{Sp}$, the foreset inclination is $15-20$ degrees, and intercalation of coarse- to very coarse-grained, often granular and medium-grained foresets is also present. Within one outcrop area, the foreset dip direction is unimodal, and although foresets in adjacent beds can be directed in strongly diverging directions (e.g., Figure $4 F$ ), but never in opposite directions. In the Opál Valley, coarse-grain size, charred wood debris (Figure 8A) occurs along foreset laminae in a planar cross-bedded, coarse-grained sandstone (facies Sp).

Clayey siltstones (facies Mm) are rare, can be sandy, and form up to $1.5-2 \mathrm{~m}$ thick, laterally more persistent, tabular (Figure $8 A$ ) or thinner lenticular beds that show strongly eroded upper contacts (Figure 8B,C). The latter geometry is far more common than the former. Most siltstones are massive; horizontal lamination is extremely rare, and when present it occurs in the sandier varieties. Desiccation cracks were only recorded in the railway cutting on Kálvária Hill (Figure 1B,C). Ranging in size from few $\mathrm{cm}$ to $1.5 \mathrm{~m}$, irregular and angular rip-up clasts of clayey siltstones are 

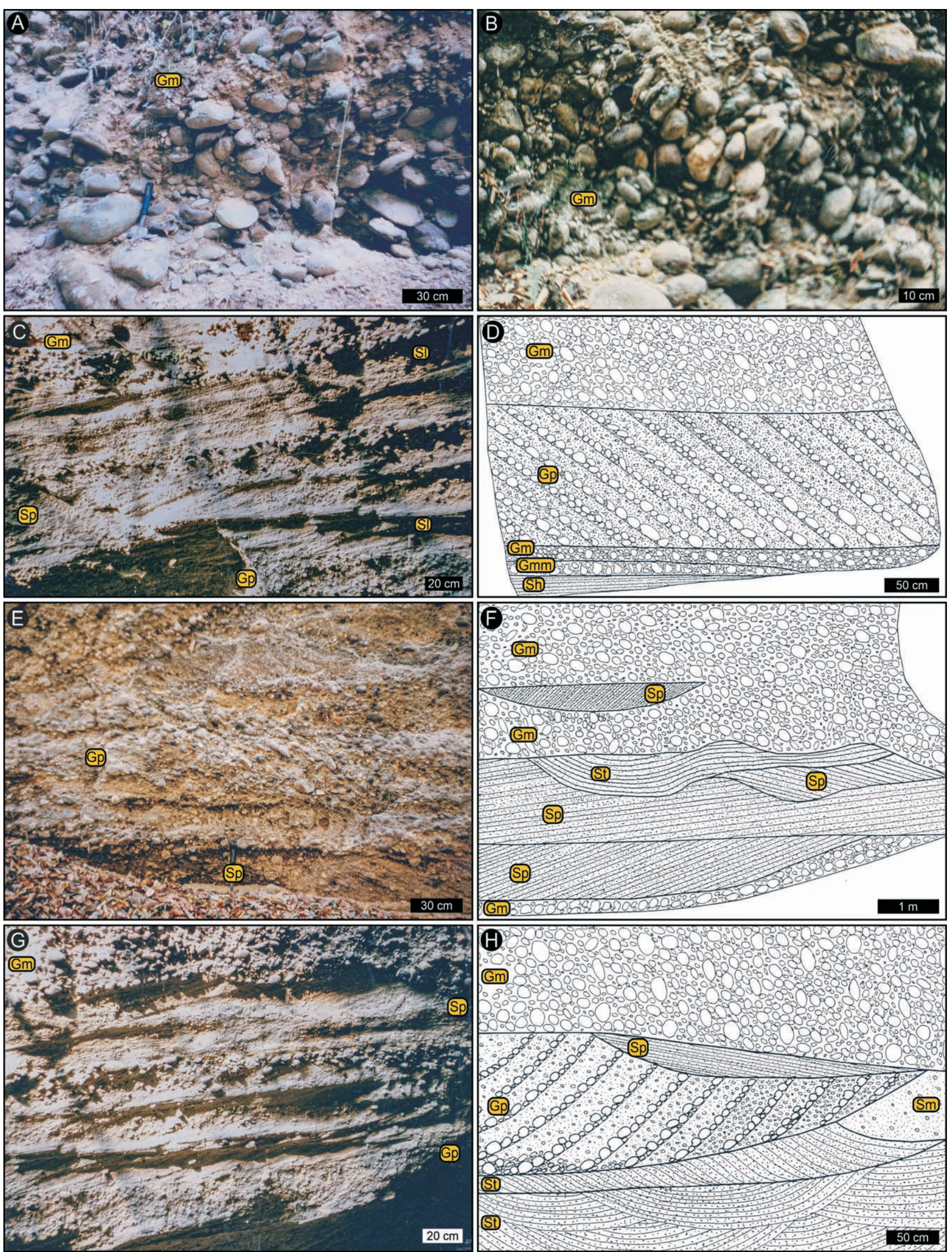

Figure 4. Close-ups of the different facies associations. Coarse-grained facies shown mainly in A-E, whereas fine-grained facies illustrated mostly in grained in F-H See text for details. For facies codes, see Table I

4. ábra. Változatos homok és konglomerátum fáciesek jellemzö váltakozása a durva- $(A-E)$ és finomszemcsés (F-H) fáciesegyüttesekben

Részletes magyarázat a szövegben és a kódokat összegzö I. táblázatban 

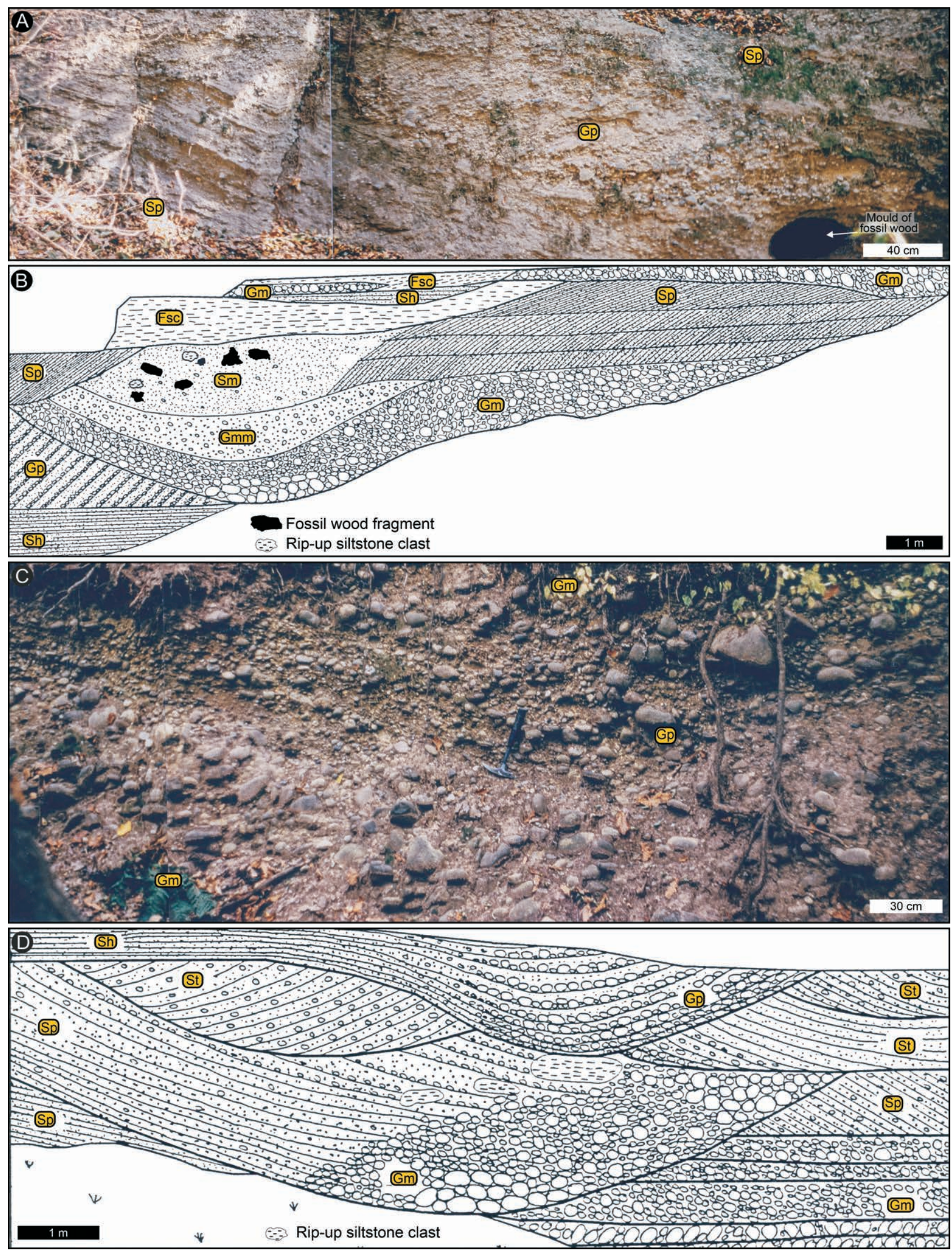

Figure 5. Four different examples of lenticular beds in the coarse- and fine-grained facies associations. Fossil wood and rip-up clasts are common in the cross-bedded and massive facies. For facies codes, see Table I

5. ábra. Kisebb-nagyobb lencse alakú testek, több méter mély mederformák a durva-és finomszemcsés fáciesegyüttesekben. Kövült fatörzsek és feltépett agyagkavicsok is gyakoriak a keresztrétegzett és a szerkezetmentes fáciesben is. A fácieskódok magyarázata az I. táblázatban 

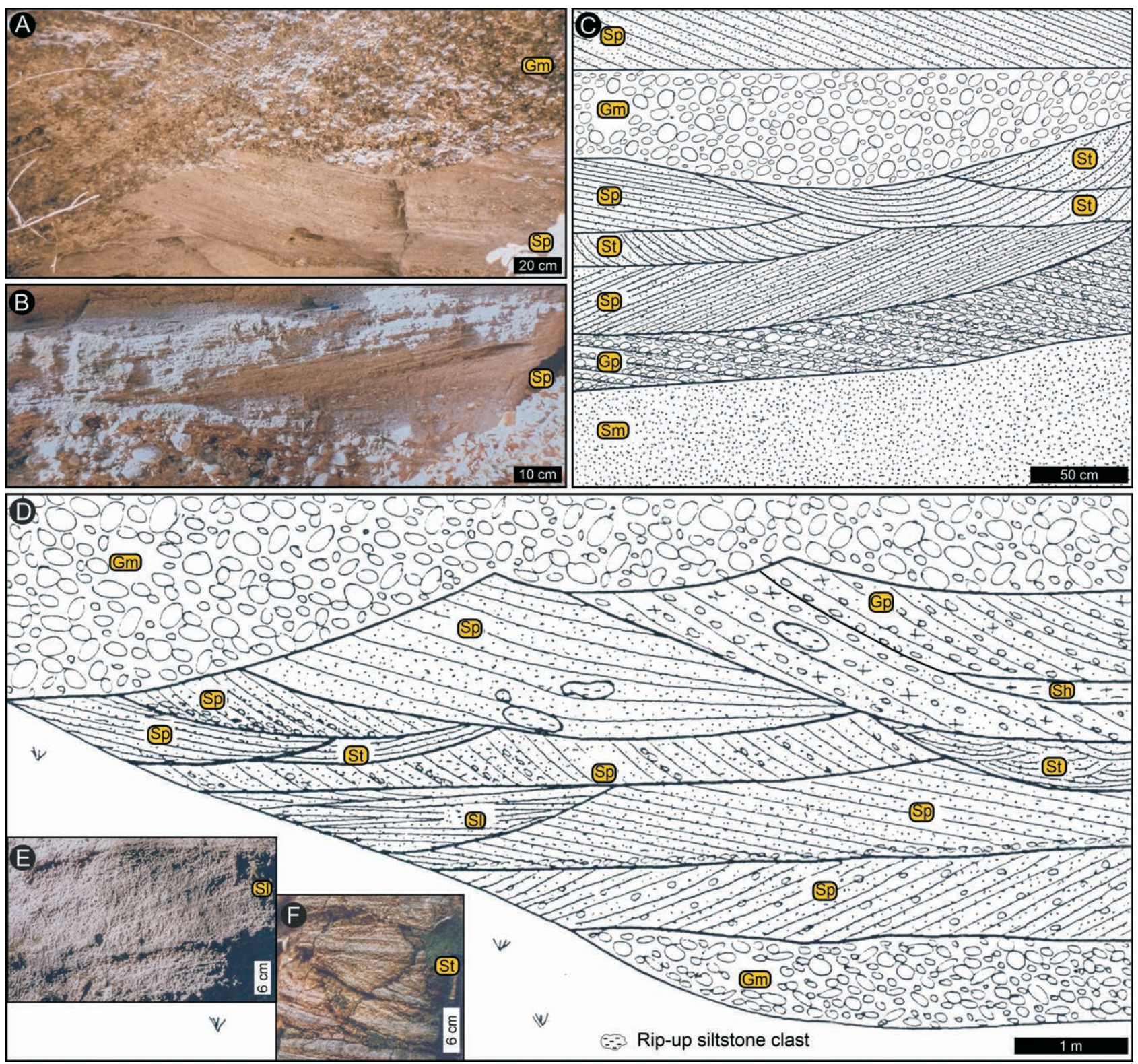

Figure 6. Close-ups of various types of cross-bedded sandy facies from the fine-grained facies association See text for details. For facies codes, see Table I

6. ábra. Különböző keresztrétegzésü homokfáciesek a finomszemcsés fáciesegyüttesben

Részletes magyarázat a szövegben és a kódokat összegző I. táblázatban

common in the cross-bedded conglomerates and sandstones (Figures 5B, 5D, 6D, 8B, 8C). Among the volcaniclastic facies types, leaf impressions (Figures $8 D, 7 E$ ) and fossil wood fragments with a blackened outer crust (either charred or coalified) are most common in facies $\mathrm{Mm}$.

\section{Facies interpretation}

The following general characteristics of the volcaniclastics $\mathrm{N}$ of Nógrádszakál collectively point to an alluvial depositional setting: limited lateral continuity of the beds that prevents their correlation; the lenticular, channel-form bed geometries; the presence of the fining-upwards successions; the textural and compositional submaturity of the clasts; the smooth, chatter-marks free quarzitic clasts; the high abundance of clast imbrication, sharp erosion surfaces and crossbedded layers; the unidirectional, high consistency palaeocurrent data, and last but not least, the dominance of fossil continental biota (both vertebrates and plant fossils).

More specifically, the conglomerates (facies Gm, Gmm, $\mathrm{Gp)}$ in the coarse-grained facies association signal high energy, powerful currents during deposition. In particular, the common, clast-supported facies types ( $\mathrm{Gm}, \mathrm{Gp}$ ) are likely products of extensive gravel sheets or bars that migrated in the direction of traction currents. The coarsegrained sediments were carried as bedload during peak flow conditions (Rust 1978, Collinson 1996). Typically, such extensive gravel sheets and bars lack internal structures, 

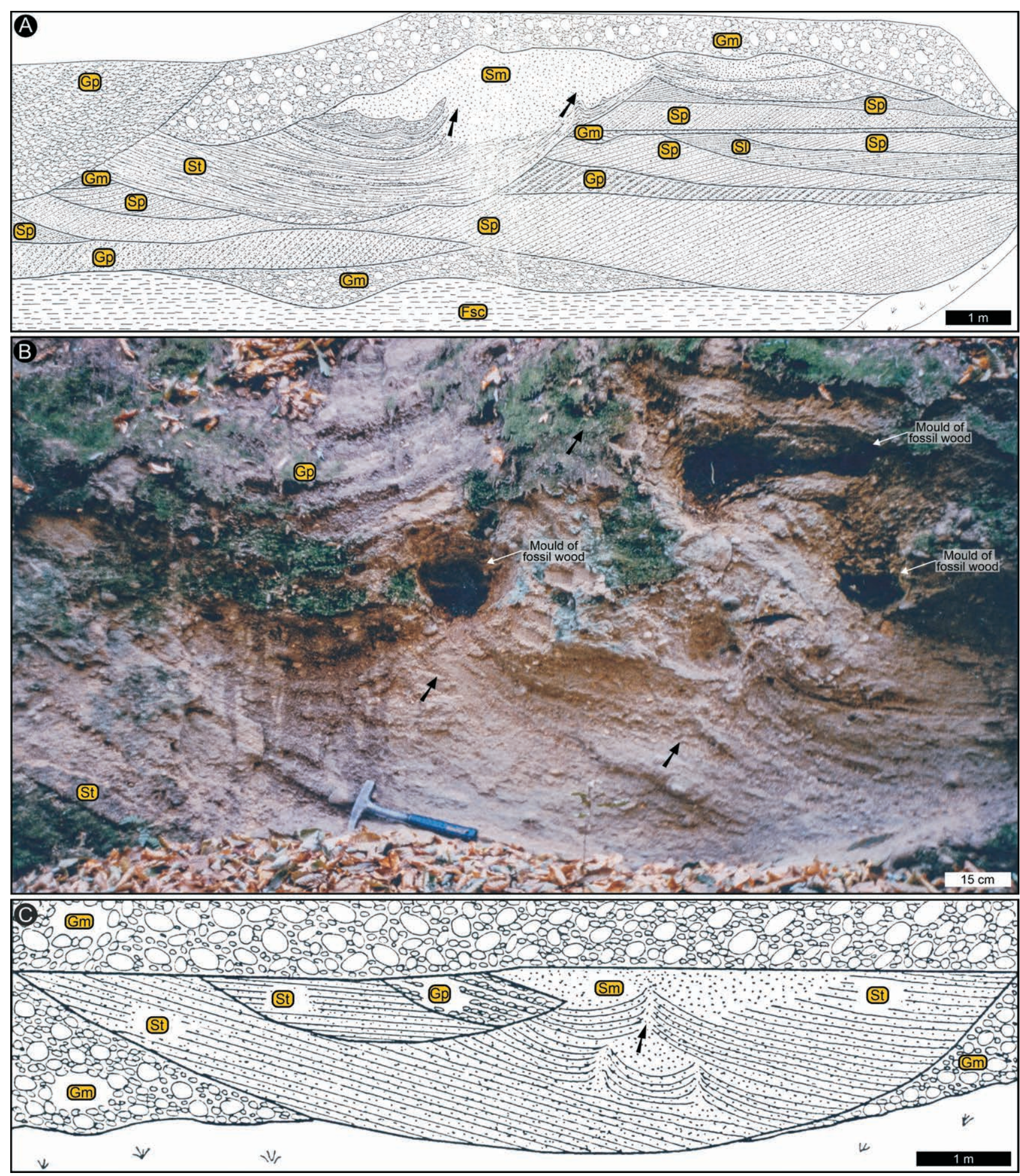

Figure 7. Water-escape structures (marked with black arrows) in cross-stratified ( $\mathrm{St}$ ) and massive ( $\mathrm{Sm}$ ) sandstones of the fine-grained facies association Note the moulds of fossils wood. For facies codes, see Table I

7. ábra. Vizkiszökési kürtök (fekete nyilak) vályús keresztrétegzettségü (St) és szerkezetmentes (Sm) homok fáciesben a finomszemcsés fáciesegyüttesben. Kövültfatörzsekágak lenyomata is figyelemre méltó

Részletes magyarázat a szövegben és a kódokat összegzỏ I. táblázatban

except for clast imbrication and rare, faint horizontal bedding. Moreover, they often show upward and downcurrent clast size decrease (SMITH 1974, REID \& FROSTICK 1994, Collinson 1996). The high abundance of the erosional surfaces that bound these facies types (e.g., Figures 4-8) indicate that the energy level, and possibly the water level too, fluctuated during deposition, conditions that are common during waning flow (Miall 1996). 

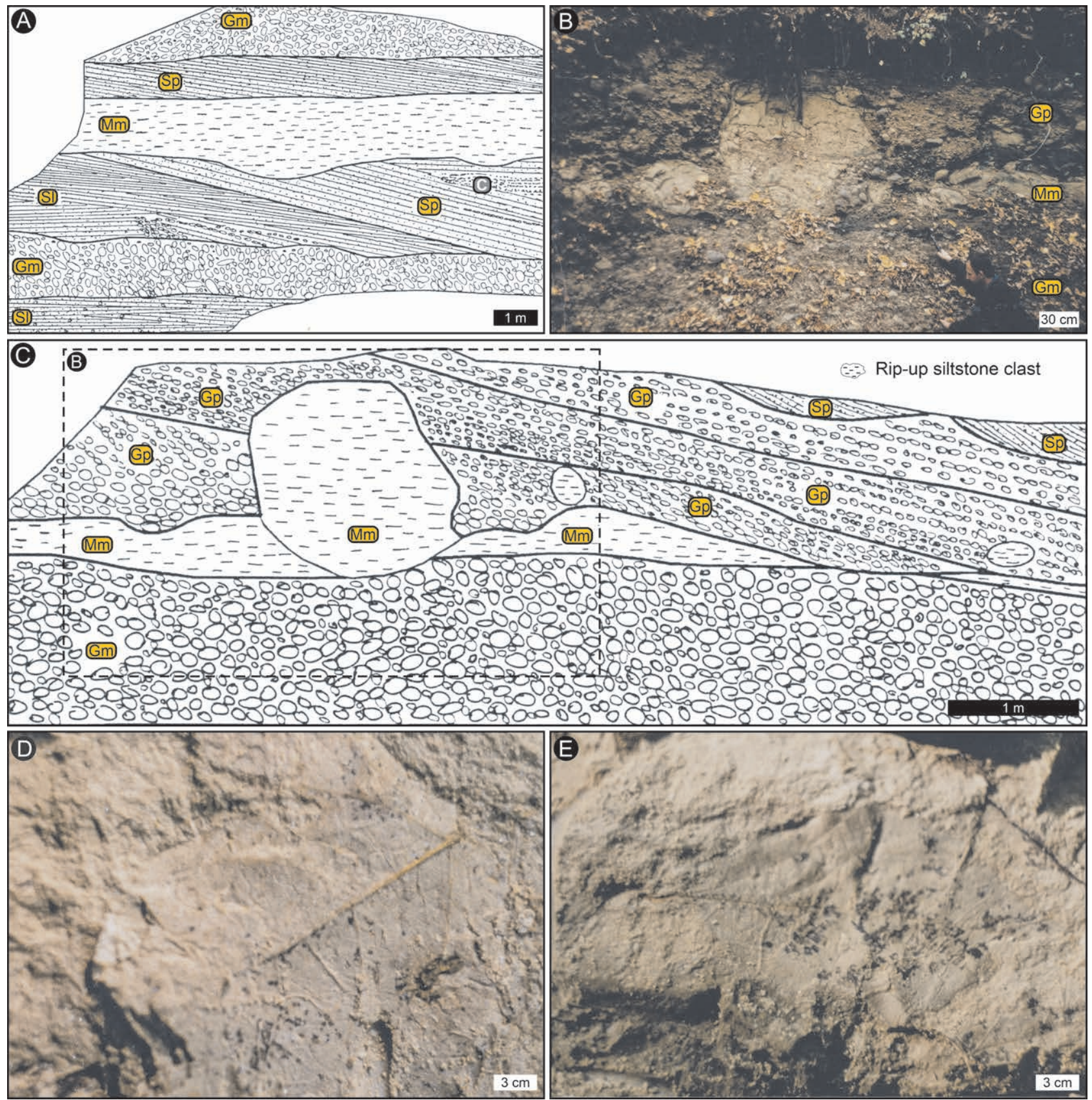

Figure 8. Clayey siltstone facies ( $\mathrm{Mm}$ ) of the fine-grained sedimentary facies associations with charred wood debris (marked with ' $\mathrm{C}$ ' in $\mathrm{A}$ ) and leaf impressions (in D and E). Rip-up mud-clasts up to a meter size are shown on B and C

See text for details. For facies codes, see Table I

8. ábra. Agyagosaleurolit-fácies (Mm) a finomszemcsés fáciesegyüttesben szénült fatörmelékkel („C” jelzi az A)ábrán) és növénylenyomatokkal (D és E). B) és C) méter átméröjü és kisebb feltépett agyagklasztok

Részletes magyarázat a szövegben és a kódokat összegzó I. táblázatban

Matrix-supported conglomerates (facies Gmm) nested within and interbedded with clast-supported conglomerates (facies $\mathrm{Gm}$ ) have also been explained with lowering and fluctuating discharge (STEel \& THOMPSON 1983, REID \& FrosticK 1994). Facies Gmm may be the product of rapid deposition from mass movements (Table I) but could also result from natural sediment sieving processes. This occurs after peak discharge, when the deposition of the coarsest clast fraction is followed by that of the finer (sand, silt) size particles, which can infiltrate among the larger clasts, in situ displacing their originally close-fitting clast fabric and decreasing the sorting (e.g., Collinson 1996). Moreover, intercalation of sandy and pebbly foresets in cross-bedded conglomerates (facies Gp; Figure $4 E$ ) are also evidence for fluctuating discharge (REID \& FROSTICK 1994). The lenticular conglomerates (Figures 5, 6) are interpreted as small- to medium-size channels (see below).

Relative to the coarse-grained facies association, the 
sandstones in the fine-grained facies association are interpreted as sediments that originate from moderate energy currents. The cross-bedded sandstone facies (Sp, St, Sl) are considered here as deposits of down-current migrating, inchannel sand dunes that formed under variable, but overall moderate flow strength, typical during lower discharge periods (Table I). Because the outcrops are not high-quality, three-dimensional exposures, it is possible that the diverging forests in facies Sp are in fact partially exposed trough crossbeds (facies $\mathrm{St}$ ), and thus their scarcity is somewhat apparent. Alternatively, the diverging $\mathrm{Sp}$ forests may have resulted during waning flow, when flow within the main channel might have bifurcated into shallow and slightly diverging subordinate channels. The preserved maximum thickness of planar cross-beds $(\sim 2.3 \mathrm{~m})$ is a reasonable proxy for the minimum height of in-channel bedforms, which in turn can help estimate the palaeo-channel depth. For this, the ratio between the height of sand bars and total bankfull depth in the modern Brahmaputra River is used (MIALL 2006). This ratio is $\sim 0.5$, which would imply medium-sized, fairly shallow fluvial channels (MIALL 2006). This estimated value of 4-5-m-deep channels in the late Badenian is similar to the channel-depth estimates proposed for gravel-bed braided rivers by LUNT et al. (2004). It is worth noting that because in small outcrops the true thicknesses of facies Gm (Figure 2) is difficult to ascertain (see Figure $4 F$, where without the sandstones lens, the thickness of facies $\mathrm{Gm}$ could be overestimated), and thus using the thickness of the conglomerate beds as channel-depth proxies might be misleading.

Massive conglomerates and sandstones (facies Gmm and Sm; Table I), the well-developed water escape abundance (Figure 7), the abundance of plant fossils and the extremely rare occurrence of desiccation cracks can be taken collectively to indicate rapid sedimentation in a permanently wet, moist, and overall high energy setting that was rarely if ever subjected to major, persistent dry episodes. The clayey siltstones represent the lowest energy deposition in the study area, which likely occurred during waning flows (Table I). Traditionally in fluvial systems (e.g., Miall 1985, 1996), such fine-grained facies are associated with overbank sedimentation or within channel settling of suspended sediment during low discharge periods. The predominantly lenticular, often eroded geometry (Figures $8 B, 8 C$ ) of the facies and its subordinate overall abundance (Figure 2) show that facies Mm is likely associated with settling from suspension within channels. The latter configuration is also supported by the occurrence of the facies as rip-up clasts within coarser grained facies (Gp, Sp) associated with higher energy depositional conditions (Figures $5 B$, $6 D, 8 B, 8 C)$.

\section{Discussion}

Based on field sedimentological evidence, the volcaniclastics $\mathrm{N}$ of Nógrádszakál originated in a high energy alluvial system where extensive gravel sheets and subordinate finer grained (sandy, silty) layers were deposited within medium-sized, approximately 4-5 m deep, low sinuosity fluvial channels. This high energy alluvial setting was permanently wet, moist, and was subjected to frequent discharge fluctuation but rarely to any persistent desiccation. The fluctuating discharge during the depositional events is also supported by the clast size analysis conducted by Tuba (1985).

Pebble to cobble clast-size populations with the overall characteristics shown in the volcaniclastics N of Nógrádszakál require bedload-carrying, competent transport medium that are common in (but not limited to) steep gradient rivers and on alluvial fans in proximal intermountain regions (RUST 1978, Miall 1992, CyPles et al. 2020). Typically, such high energy channels have low sinuosity and form a braided network of unstable, laterally shifting channels (e.g., Rust 1978, MiALL 1992). The mobility of the channels is chiefly driven by the high amount of bedload-transported sediment, which being non-cohesive and sparsely vegetated, becomes repeatedly mobilized and thus impedes the establishment of stabile channel margins (e.g., Rust 1978, ReID \& Frostick 1994, Miall 1992, Collinson 1996).

Braided channel networks on alluvial fans and in fluvial systems (including alluvial plains) within the proximal parts of basins deposit sediments with high facies similarity and differentiating their products in sedimentary record remains elusive even if exposed in high quality (i.e., large and 3dimentional) outcrops (e.g., RUST 1978; HEwARD 1978; MialL 1978a, b, 1992, 1996, 2006, 2016; Rust \& KosTer 1984; BRIDGE 1993; LunT et al. 2004; HARVEY et al. 2005; SAMBRoOK SMith et al. 2006, HartLey et al. 2010, CyPles et al. 2020). In case of alluvial fans, especially in large systems, some of the often cited criteria for their identification are: (1) the abrupt facies changes in proximal-to-distal regions, (2) radial palaeocurrent distribution (i.e., low consistency ratio), and (3) higher abundance of mass movement (debris flow) deposits, especially in the proximal regions (e.g., RUST 1978, Miall 1978b, Rust \& Koster 1984, Ventra \& Clarke 2018). The volcaniclastics N of Nógrádszakál do not appear to meet the above criteria for alluvial fans, however excluding the possibility that they formed on an alluvial fan is not warranted, because the current data is limited to a small study area that is lacking high-quality exposures. Even though the uncertainty in determining the exact depositional environment remains high with the available data, it is postulated that the low sinuosity channels were likely part of a proximal braided fluvial system rather than an alluvial fan. This assertion is supported by the varied clast composition in the volcaniclastics, which, albeit in low abundance, contain quartz, chert, quartzite, granite, mica schist and gneiss clasts as well (in addition to the omnipresent andesites). It is possible that the rare non-andesitic clasts may have been sourced by igneous processes as xenoliths from pre-Badenian units. However, this mixed clast composition together with the palaeocurrent indicators are better explained with a heterogenic source area to the $\sim \mathrm{N}$ and $\sim \mathrm{E}$ of Nógrádszakál, for which there is ample evidence in the geological make-up of those areas (e.g., borehole Bu-4 in PRAKFALVI 1996, also see MINGEO 1987, 
PlašIENKA 2018). Moreover, a proximal fluvial system at Nógrádszakál is also more likely than an alluvial fan when considering not only the overall thickness of the volcaniclastics but also the dominant palaeocurrent direction in the context of the late Badenian regional palaeogeography (Figure 1A, e.g., Kováč et al. 2017).

The study area appears to have been the downslope extension of the Lysec foothills to the SE as shown by geological characters of the upper Badenian volcaniclastics (i.e., pyroclastics and volcaniclastics) that are exposed NW of Nógrádszakál in southern Slovakia (e.g., BALOGH et al. 1966; KonEČNÝ et al. 1983, 1995; KUN-JÁGER 1997). This is supported by our observation of the southern Slovakian volcaniclastics, which are characterized by an overall clast population that is on average larger, less rounded, more monomictic (with only $1 \%$ of clasts being non-andesites). These differences are minor and can be explained by the proximal, more source-ward position (i.e., closer to the Lysec volcano) of the southern Slovakian sites relative to those N of Nógrádszakál (c.f., DAVIES et al. 1978, FISHER \& SCHMINCKE 1994, ORTON 1996). Moreover, the pyroclastics (andesitic tuff-breccias, andesitic tuffs, andesitic lapilli tuffs, etc.) that are interbedded with the volcaniclastics (Figure $1 B, 1 C$ ) are also similar in the two regions and were likely and mainly sourced from the andesites of the Lysec palaeo-volcano in the late Badenian. The two levels of volcaniclastics occurring within the pyroclastics (Figure $1 B, 1 C$ ) are explained by the discontinuous eruption history of the Lysec palaeo-volcano, with the volcaniclastics having been mainly deposited in the quiet, inter-eruption episodes, whereas the pyroclastics representing the syn-eruptive times when pyroclastic flows (block-and-ash flows) and also lahars occurred (e.g., KONEČNÝ et al. 1995; KUN-JÁGER 1997; LEXA et al. 2010). As common in active volcanic regions (e.g., DAVIES et al. 1978, FISHER \& SCHMINCKE 1994, ORTON 1996), the syn-eruptive deposits on the foothills of the Lysec palaeo-volcano were reworked by powerful alluvial processes, which at least in the sector $\mathrm{N}$ of Nógrádszakál, occurred in braided channels that drained initially from $\sim \mathrm{N}$ to $\sim \mathrm{S}$ and then from $\sim \mathrm{E}$ to $\sim \mathrm{W}$ (Figure 3). The water level fluctuations in these braided channels (Figure 9) were likely driven by discharge fluctuations linked to seasonal variation in precipitation. Moreover, as typical in braided rivers (e.g., RUST 1978; HEWARD 1978; Miall 1978a, b, 1992, 1996, 2006, 2016; Rust \& Koster 1984; BRIDGE 1993; LUNT et al. 2004), scouring of channels and transportation of sediments occurred during high flow stages, whereas deposition, via the expansion/generation of gravel sheets and sand bars, took place during low flow stages.

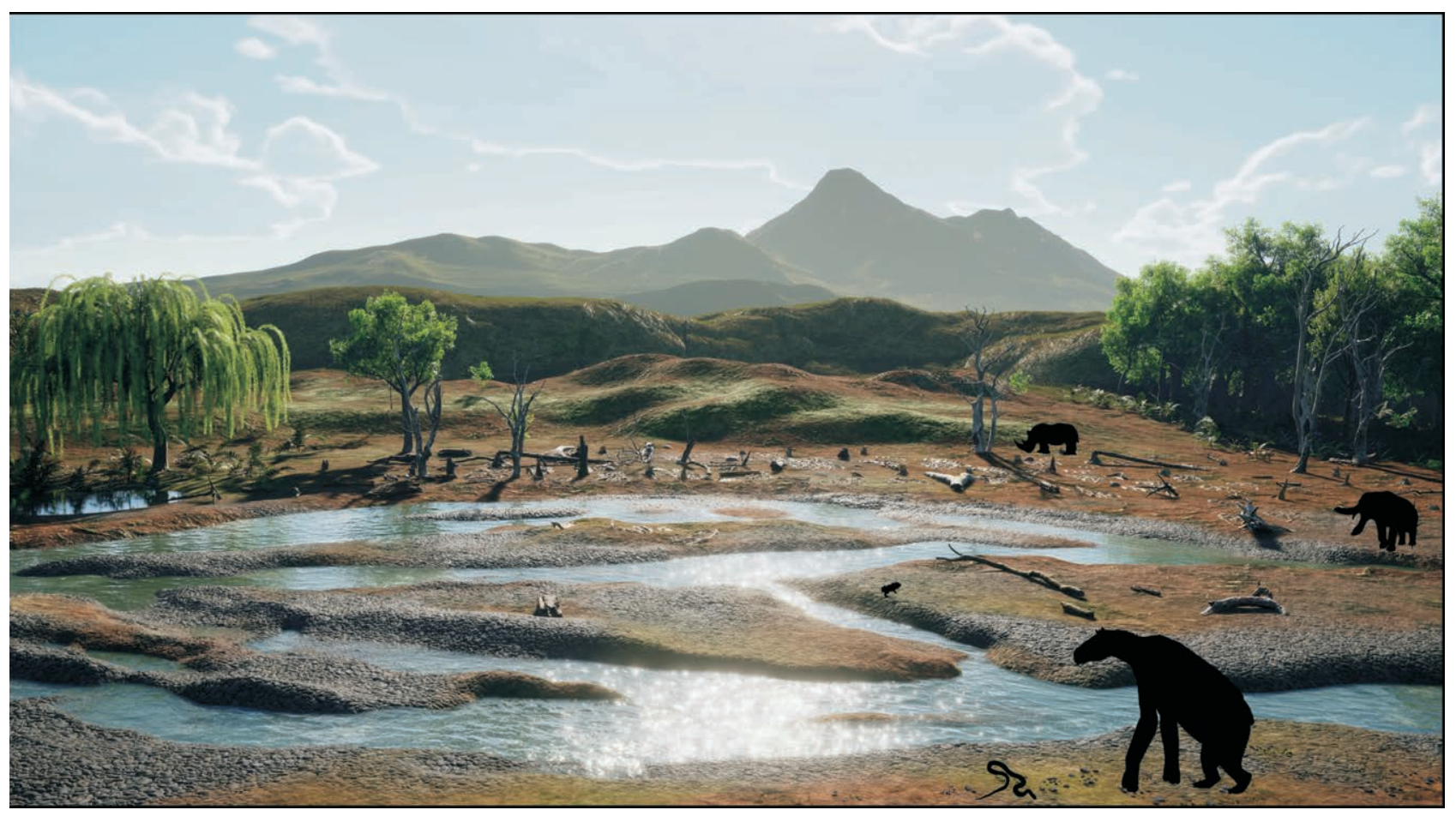

Figure 9. Late Badenian environment N of Nógrádszakál

Foreground: gravel-bed, braided river during moderate flow stage with the outlines of the key terrestrial biota (e.g., megaherbivores, frogs, snakes) including some plant types (e.g., Ulmus, Salix, Alnus). Background: the highest mountain is the temporarily dormant Lysec palaeo-volcano. Fauna silhouettes from PhyloPic.com by Steven TRAVER, Nobu TAMURA, Beth ReINKE (adapted under creativecommons.org/licenses/by/3.0/) as well as GASPARIK 2004 with the permission of the author. The animation of the palaeo-environment (without animals) is available here: https://youtu.be/hUbxilQJNFk

9. ábra. Késö badeni őskörnyezeti rekonstrukció a mai Nógrádszakáltól északra

Az elötérben közepes vizállással a kavicsos medrü, fonatos folyó a környezö élövilág fö képviselöivel, nagy testü növényevőkkel, gerincesekkel (békák, kígyók) és a jellegzetes növényzettel (pl. szil-, füz-, éger-félék). A háttérben a klasztok forrásául szolgáló, éppen szunnyadó Lysec paleovulkán magasodik. A faunakörvonalak forrása: PhyloPic.com (Steven TRAVER, Nobu TAMURA, Beth REINKE munkái, creativecommons.org/licenses/by/3.0/) és GASPARIK 2004 (a szerzö engedélyével). Az öskörnyezeti rekonstrukció animációja (állatok nélkül) itt tekinthetö meg: https://youtu.be/hUbxiIQJNFk 
The abundance and the large size of allochthonous fossil wood in the volcaniclastics $\mathrm{N}$ of Nógrádszakál (for their distribution and maximum size, also see PrAKFALVI 2012) are taken as evidence for destructive natural events (e.g., volcanic eruptions, high magnitude floods) that were capable of uprooting and transporting mature trees. Additionally, those fossil wood fragments that have charred/coalified outer crusts as well as the charred plant debris (Figure $8 A$ ) could indicate wildfires, which have been linked to massive sedimentation events in the geological record not only in volcanically active areas but also in regions of high plant productivity (e.g., BELCHER et al. 2013, MuIR et al. 2015, BORDY et al. 2018). As it is evident from the abundance and richness of plant fossils (KORDOS-SZAKÁLY 1984a, b) and well as the megaherbivore remains (GAÁl 1905, SCHLESINGER 1922, GASPARIK 2001, HÍR 1993) collected in the study area, the Nógrádszakál landscape in the late Badenian was lushly vegetated (Figure 9) and thus supplied abundant accumulations of dry biomass, which could fuel potential wildfires.

As illustrated by the regional palaeogeography (e.g., KARÁtSON et al. 2001, Kováč et al. 2017, Di CAPUA et al. 2021) as well as the marine affinity of the oldest fossils (e.g., ray and shark teeth, sponge spicules - HíR 1993) recovered from the basalmost volcaniclastics $\mathrm{N}$ of Nógrádszakál, the late Badenian palaeoshoreline was in the southern proximity. However, with time, due to the intensification of the Lysec volcanic activities and regional geodynamics (e.g., KONEČNÝ et al. 1995, Kováč et al. 2017), the shoreline migrated further south, and this increased the relative proportion of continental depositional settings in this region. In addition, similar middle Miocene volcano-sedimentary settings have been reconstructed at the southern foothills of the Štiavnica Stratovolcano and Vtáčnik Volcanic Field (e.g., Zlaté Moravce Formation; ŠARINOvÁ et al. 2018). Moreover, a coastal upper Badenian setting was documented at the foothills of the Visegrád-BörzsönyBurda Volcanic Field as well (Nováková et al. 2020). In the view of the regional paleogeography (Figure 1A), and the paleo-currents documented here (Figure 3), it is possible that the late Badenian braided fluvial system near Nógrádszakál continued towards west-southwest, until it reached the shoreline of the North Central Paratethys Sea.

With the available data, it is difficult to ascertain temporal changes from the lower to the upper volcaniclastic levels $\mathrm{N}$ of Nógrádszakál, however the larger clast size (Figure 2) and eastward directed palaeoflow (Figure 3) are noted in the upper level. This could be explained with the changes in drainage both in its intensity and direction. The cause of the drainage direction change remains elusive. It may be linked to voluminous volcanic detritus supply (e.g., MANVILLE et al. 2007, 2009; MAJOR 2020), a climate that became wetter, tectonics that increased the regional palaeoslope gradients or a combination of these effects. The sedimentological evidence in the study area is not suitable to meaningfully demonstrate any climate change. Without attempting to promote a single occurrence of desiccation cracks as climate proxy, it is noted that these sedimentary structures only occur in the upper level. The onset of a wetter climate during the deposition of the studied stratigraphic interval is to some extent supported by the palaeobotanical findings of KORDOS-SZAKÁLY (1984b, p. 55), who showed that relative to the lowermost level, the middle pyroclastic level (sampled in the Páris-patak Valley) revealed a more varied and allochthonous plant fossil assemblage that also contains taxa requiring wetter conditions, in proximity of water (in addition to evergreen taxa and those needing riparian conditions as well as "drier soil and a slope with southern exposure"). The potential increase in slope relief also might be connected to uplift in the northern part of the Pannonian Basin. This could have been related to largescale processes like mantle upwelling below the volcanic edifice (e.g., HARANGI \& LENKEY 2007, HARANGI \& LUKÁCS 2019) or to smaller-scale tilting and uplift of footwall blocks between extensional half grabens (e.g., FODOR et al. 1999, BALÁzS et al. 2018, BEKE et al. 2019, ŠUJAN et al. 2021).

\section{Conclusion}

The upper Badenian volcaniclastics, comprising pyroclastics and volcaniclastics exposed N and NW of Nógrádszakál in Hungary and southern Slovakia, respectively, are the deposits that formed during syn- and inter-eruptive depositional phases of the late Badenian Lysec volcano. The sedimentological characteristics of the volcaniclastics $\mathrm{N}$ of Nógrádszakál show that the andesite conglomerate-dominated, fining-upwards successions were deposited as gravel sheets and sand bars in a high energy braided fluvial system with medium-sized, 4-5 m deep, low sinuosity channels. Initially, the drainage was southwards but with time it became westwards directed. The alluvial setting was permanently wet, moist, and was subjected to discharge fluctuations, likely during large, seasonal downpour events. The lushly vegetated landscape was not only home to megaherbivores, frogs and snakes, but also to a diverse and rich plant population that supplied fuel to potential wildfires and abundant woody debris that was entombed in the alluvial sediments.

\section{Acknowledgements}

We dedicate this paper to our late professor, colleague and friend András NagYMarosy, who introduced us to the Badenian geological history of this region and supported us in our fledging geological careers. Special thanks are due to Róbert NAGY for assistance in generating the animation of the palaeo-environmental reconstruction in World Machine. This paper benefitted from discussions with László FoDOR, Árpád MAGYARI, László Csontos, László KoRDOs, Mihály GaSPARIK and Frici PuszTa. We thank reviewers Samuel Rybár and Andrea DI CAPUA, as well as editor László FODOR for their constructive comments. Opinions expressed and conclusions arrived at are the responsibility solely of the authors. During the research, EB was a Hungarian Republic bursar. 


\section{References-Irodalom}

Balázs, A., Matenco, L., Vogt, K., Cloetingh, S. \& Gerya, T. 2018: Extensional polarity change in continental rifts: Inferences from 3D numerical modeling and observations. - Journal of Geophysical Research: Solid Earth 123, 8073-8094. https://doi.org/ 10.1029/2018JB015643

BALOGH K., BARTKó L., LÁNG S. \& SzỨCS L. 1966: Magyarázó Magyarország M=1:200 000-es földtani térképsorozatához M-34-XXXII, Salgótarján. - Magyar Államib Földtani Intézet, Budapest 155 p.

BARTKó L. 1952: A salgótarjáni barnakőszén medence ÉNy-i részének földtani viszonyai. - A Magyar Állami Földtani Intézet Évi Jelentése 1948-ról, Budapest, 101-110.

Beke, B., Fodor, L., Millar, L. \& Petrik, A. 2019: Deformation band formation as a function of progressive burial: depth calibration and mechanism change in the Pannonian Basin (Hungary). - Marine and Petroleum Geology 105, 1-16. https://doi.org/10.1016/ j.marpetgeo.2019.04.006

Belcher, C. M., Collinson, M. E. \& Scott, A. C. 2013: A 450-million-year history of fire. - In: Belcher C. M. (ed.): Fire Phenomena and the Earth System: An Interdisciplinary Guide to Fire Science. - John Wiley \& Sons, Oxford, 229-249. https://doi.org/ 10.1002/9781118529539.ch12

Bogsch L. 1942: A Litke-Rákospuszta-Nógrádszakál közötti terület földtani viszonyai. - A Magyar Állami Földtani Intézet Évi Jelentése 1936-38/2, 1101-1110.

Bordy, E. M., Bowen, D. A., Moore, J., Garnett, M. H. \& Tsikos, H. 2018: A Holocene "Frozen Accident": Sediments of Extreme Paleofloods and Fires in the Bedrock-Confined Upper Huis River, Western Cape, South Africa. - Journal of Sedimentary Research 88, 696-716. https://doi.org/10.2110/jsr.2018.29

BRIDGE, J. S. 1993: The interaction between channel geometry, water flow, sediment transport and deposition in braided rivers. - In: BEST J. L. \& Bristow C. S. (eds): Braided Rivers. Special Publications Geological Society of London 75, 13-71. https://doi.org/ 10.1144/GSL.SP.1993.075.01.02

Chernyshev, I. V., KonečnÝ, V., Lexa, J., Kovalenker, V. A., Jeleň, S., Lebedev, V. A \& Goltsman, Y. V. 2013: K-Ar and Rb-Sr geochronology and evolution of the Štiavnica Stratovolcano (Central Slovakia). - Geologica Carpathica 64, 327-351. https://doi.org/ 10.2478/geoca-2013-0023

Collinson, J. D. 1996: Alluvial sediments. - In: Reading, H. G. (ed.): Sedimentary Environments: Processes, Practices and Stratigraphy. Blackwell Science, Oxford, 37-82.

CYPLES, N. N., IELPI, A. \& DirszowsKy, R. W. 2020: Planform and stratigraphic signature of proximal braided streams: remote-sensing and ground-penetrating-radar analysis of the Kicking Horse River, Canadian Rocky Mountains. - Journal of Sedimentary Research 90, 131-149. https://doi.org/10.2110/jsr.2020.6

DASGUPTA, P. 2002: Determination of paleocurrent direction from oblique sections of trough cross-stratification - a precise approach. Journal of Sedimentary Research 72, 217-219. https://doi.org/10.1306/050401720217

Davies, D. K.,Vessell, R. K., Miles, R. C., Foley, M. G. \& Bonis, S. B. 1978: Fluvial transport and downstream sediment modification in an active volcanic region. - In: Miall, A. D. (ed.): Fluvial Sedimentology. Memoir of the Geological Survey of Canada 5, 61-84.

Di Capua, A., Barilaro, F., Szepesi, J., Lukács, R., Gál, P., Norini, G., Sulpizio, R., Soós, I., Harangi, S. \& Groppelli, G., 2021: Correlating volcanic dynamics and the construction of a submarine volcanogenic apron: An example from the Badenian (Middle Miocene) of North-Eastern Hungary. - Marine and Petroleum Geology 126, p. 104944. https://doi.org/10.1016/j.marpetgeo. 2021.104944

FisheR, R. V. \& SCHMincKe H.-U. 1994: Volcaniclastic sediment transport and deposition. - In: Pye, K. (ed.): Sediment Transport and Deposition Processes. Blackwell Scientific Publication, Oxford, 351-384.

Fodor, L., Csontos, L., BAdA, G., Györfi, I. \& BenKovics, L. 1999: Tertiary tectonic evolution of the Pannonian basin system and neighbouring orogens: a new synthesis of paleostress data. - In: Durand, B., Jolivet, L., Horváth, F. \& Séranne, M. (eds): The Mediterranean Basins: Tertiary extension within the Alpine Orogen. Geological Society, London, Special Publications 156, 295334. https://doi.org/10.1144/gsl.sp.1999.156.01.15

GASPARIK, M. 2001: Neogene proboscidean remains from Hungary: an overview. - Fragmenta Palaeontologica Hungarica 19, 61-67.

GASPARIK M. 2004: Magyarországi neogén és alsó-pleisztocén Proboscidea maradványok. - Doctoral thesis, ELTE TTK Ốslénytani Tanszék, Budapest, 1-129.

GAÁL I. 1905: Adatok az Osztroski-Vepor andesit-tufáinak mediterrán faunájához. - Földtani Közlöny 35/ 6-7, $288-313$.

HÁMOR G. 1985: A Nógrád-cserháti kutatási terület földtani viszonyai. - Geologica Hungarica Series Geologica 22, 307 p.

HÁMOR G. 1997: A magyarországi miocén fejlődéstörténete és ősföldrajza. - In: HAAs J. (szerk.): Fülöp József emlékkönyv. Akadémiai Kiadó, Budapest, 231-250.

Harangi, Sz. \& Lenkey, L. S. 2007: Genesis of the Neogene to Quaternary volcanism in the Carpathian-Pannonian region: Role of subduction, extension, and mantle plume. - In: Beccaluva, L., Bianchini, G. \& Wilson, M. (eds): Cenozoic Volcanism in the Mediterranean Area. Special Paper of the Geological Society of America 418, 67-92. http://dx.doi.org/10.1130/2007.2418(04)

HARANGI Sz. \& LUKÁCS R. 2019: A Kárpát-Pannon térség neogén-kvarter vulkanizmusa és geodinamikai kapcsolata. - Földtani Közlöny 149, 197-232. https://doi.org/10.23928/foldt.kozl.2019.149.3.197

Hartley, A. J., Weissmann, G. S., Nichols, G. J. \& Warwick, G. L. 2010: Large distributive fluvial systems: characteristics, distribution, and controls on development. - Journal of Sedimentary Research 80, 167-183. https://doi.org/10.2110/jsr.2010.016

Harvey, A. M., Mather, A. E. \& Stokes, M. 2005: Alluvial fans: geomorphology, sedimentology, dynamics-introduction. A review of alluvial-fan research. - Special Publications Geological Society of London 251, 1-7. https://doi.org/10.1144/ gsl.sp.2005.251.01.01 
Heward, A. P. 1978: Alluvial fan sequence and megasequence models: with examples from Westphalian D-Stephanian B Coalfields, Northern Spain. - In: MiAll, A. D. (ed.): Fluvial Sedimentology. Memoir of the Geological Survey of Canada 5, 669-702.

High, L. R. \& PicARD, M. D. 1974: Reliability of cross-stratification types as paleocurrent indicators in fluvial rocks. - Journal of Sedimentary Research 44, 158-168. https://doi.org/10.1306/74d729af-2b21-11d7-8648000102c1865d

Hír, J. 1993: Presence of Chalocotherium grande (Blainville, 1849) (Mammalia, Perissodactyla) in the Paris Valley at Nógrádszakál. Nógrád Megyei Múzeumok Évkönyve 1993, 233-246.

Hír, J. 2013: Early and Middle Miocene (MN5-MN6) transitional rodent fauna from Litke (North Hungary, Nógrád County). Fragmenta Palaeontologica Hungarica 30, 101-137.

Hír, J., Venczel, M., Codrea, V., Angelone, C., van den Hoek Ostende, L.W., Kirscher, U. \& Prieto, J. 2016: Badenian and Sarmatian s. str. from the Carpathian area: Overview and ongoing research on Hungarian and Romanian small vertebrate evolution. - Comptes Rendus Palevol 15, 863-875. https://doi.org/10.1016/j.crpv.2016.08.001

HudáčKová, N., Holcová, K., Halásová, E., Kováčová, M., Doláková, N., Trubač, J., Rybár, S., Ruman, A., Stárek, D., Šujan, M., JAMrich, M. \& Kovéč, M. 2020: The Pannonian Basin System northern margin paleogeography, climate, and depositional environments in the time range during MMCT (Central Paratethys, Novohrad-Nógrád Basin, Slovakia). Palaeontologia Electronica 23/3, a50. http://dx.doi.org/10.26879/1067

Karátson, D., Csontos, L., Harangi, S., SzéKely, B. \& Kovácsvölgyi, S. 2001: Volcanic successions and the role of destructional events in the Western Mátra Mountains, Hungary: implications for the volcanic structures. - Géomorphologie: relief, processus, environnement 7, 79-92. http://dx.doi.org/10.3406/morfo.2001.1092

Kercsmár Zs. (szerk.), Budai T., Csillag G., Selmeczi I. \& Sztanó O. 2015: Magyarország felszíni képzódményeinek földtana. Magyarázó Magyarország földtani térképéhez (1:500 000). - Magyar Földtani és Geofizikai Intézet, Budapest.

KoneČnÝ, V. \& LeXA, J. 2002: Evolution of the Central Slovakia Neogene Volcanic Field related to the horst/graben structure. Proceedings of XVIIth Congress of CBGA, Bratislava, 1-4.

KoneČnÝ, V., LeXA, J. \& PlanderovÁ, E. 1983: Stratigraphy of the Central Slovakian Volcanic Field. - Západné Karpaty Séria Geológia 9, 1-203.

KoneČnÝ, V., LeXA, J. \& HoJstričovÁ, V. 1995: The Central Slovakia Neogene volcanic field: a review. - Acta Vulcanologica 7, 63-78.

Kordos-SzAKÁLY, M. 1984a: Stratigraphical revision of some Hungarian Badenian-Sarmatian floras. - Studia Botanica 18, 59-63.

KoRdOS-SZAKÁlY, M. 1984b: New data to the Miocene flora of Nógrádszakál (Hungary). - Annales historico-naturales Musei nationalis hungarici 76, 43-63.

Kováč, M., HudÁčKová, N., Halásová, E., KováčovÁ, M., Holcová, K., OszczypKo-Clowes, M., Báldi, K., Less, G., Nagymarosy, A., Ruman, A. \& KluČIAR, T. 2017: The Central Paratethys palaeoceanography: a water circulation model based on microfossil proxies, climate, and changes of depositional environment. - Acta Geologica Slovaca 9, 75-114. http://www.geopaleo.fns.uniba.sk/ ageos/articles/abstract.php?path=kovac_et_al\&vol=9\&iss=2

KUN-JÁGER E. 1997: Terepi szedimentológiai vizsgálatok és ősföldrajzi rekonstrukció Nógrádszakálon és környékén. - MSc dissertation, ELTE TTK Földtani Tanszék, Budapest, 1-90. https://doi.org/10.6084/m9.figshare.14602386.v1

Le Maitre, R. W., Streckeisen, A., Zanettin, B., Le Bas, M. J., Bonin, B. \& Bateman, P. (eds) 2005: Igneous rocks: a classification and glossary of terms. - Cambridge University Press, 256 p. https://doi.org/10.1017/CBO9780511535581

LeXa, J., Seghedi, I., Németh, K., SzaKÁcs, A., Konećny, V., Pécskay, Z., FülöP, A. \& KovÁcs, M. 2010: Neogene-Quaternary volcanic forms in the Carpathian-Pannonian Region: a review. - Central European Journal of Geosciences 2, 207-270. https://doi.org/10.2478/ v10085-010-0024-5

Lunt, I. A., BRidge, J. S. \& TyE, R. S. 2004: A quantitative, three dimensional depositional model of gravelly braided rivers. Sedimentology 51, 377-414. https://doi.org/10.1111/j.1365-3091.2004.00627.x

Mandic, O., Sant, K., KallanXhi, M. E., Ćorić, S., Theobalt, D., Grunert, P., de Leeuw, A. \& Krijgsman, W. 2019: Integrated biomagnetostratigraphy of the Badenian reference section Ugljevik in southern Pannonian Basin - implications for the Paratethys history (middle Miocene, Central Europe). - Global and Planetary Change 172, 374-395. https://doi.org/10.1016/j.gloplacha.2018.10.010

Major, J. J., 2020: Mount St. Helens at 40. - Science 368(6492), 704-705. https://doi.org/10.1126/science.abb4120

Manville, V., Hodgson, K. A. \& NAIRN, I. A., 2007: A review of break out floods from volcanogenic lakes in New Zealand. - New Zealand Journal of Geology and Geophysics 50, 131-150. https://doi.org/10.1080/00288300709509826

MANVILLE, V., NÉMETH, K. \& KANO, K. 2009: Source to sink: a review of three decades of progress in the understanding of volcaniclastic processes, deposits, and hazards. - Sedimentary Geology 220, 136-161. https://doi.org/10.1016/j.sedgeo.2009.04.022

MiaLl, A. D. 1974: Paleocurrent analysis of alluvial sediments; a discussion of directional variance and vector magnitude. - Journal of Sedimentary Research 44, 1174-1185. https://doi.org/10.1306/212f6c6c-2b24-11d7-8648000102c1865d

Miall, A. D. 1978a: Lithofacies types and vertical profile models in braided river deposits: a summary. - In: Miall, A. D. (ed.): Fluvial Sedimentology. Memoir of the Geological Survey of Canada 5, 597-604.

Miall, A. D. 1978b: Fluvial Sedimentology: a historical review. - In: Miall, A. D. (ed.): Fluvial Sedimentology. Memoir of the Geological Survey of Canada 5, 1-49.

Miall, A. D. 1985: Architectural-element analysis: a new method of facies analysis applied to fluvial deposits. - Earth-Science Reviews 22, 261-308. https://doi.org/10.2110/scn.85.19.0033

Miall, A. D. 1988: Architectural elements and bounding surfaces in fluvial deposits: anatomy of the Kayenta Formation (Lower Jurassic), Southwest Colorado. - Sedimentary Geology 55, 233-262. https://doi.org/10.1016/0037-0738(88)90133-9

Miall, A. D. 1992: Alluvial deposits. - In: Walker, R. G. \& James, N. P. (eds): Facies Models: Response to Sea Level Change. Geological Association of Canada, 119-142.

Miall, A. D. 1996: The Geology of Fluvial Deposits: Sedimentary Facies, Basin Analysis, and Petroleum Geology. - Berlin, SpringerVerlag, 582 p. https://doi.org/10.1016/s0037-0738(96)00081-4 
Miall, A. D. 2006: How do we identify big rivers? And how big is big? - Sedimentary Geology 186, 39-50. https://doi.org/10.1016/ j.sedgeo.2005.10.001

MiAll, A. D. 2016: Stratigraphy: A Modern Synthesis. - Springer-Verlag, Berlin, 454 p. https://doi.org/10.1007/978-3-319-24304-7_7

MINGEO 1987: Nógrádszakál reménybeli mélymúvelésú barnakőszénterület előkutatási terve. - MGSz Salgótarjáni Kirendeltség, Salgótarján, 1-19.

Muir, R., Bordy E. M. \& Prevec, R. 2015: Lower Cretaceous deposit reveals first evidence of a post-wildfire debris flow in the Kirkwood Formation, Algoa Basin, Eastern Cape, South Africa. - Cretaceous Research 56, 161-179. https://doi.org/10.1016/j.cretres. 2015.04.005

NovÁKovÁ, P., RYbÁR, S., ŠArinovÁ, K., NAGY, A., HudéčKovÁ, N., JAMrich, M., TEOdORidis, V., KovÁČovÁ, M., ŠuJAN, M., VlČEK, T. \& KovÁČ, M. 2020: The late Badenian - Sarmatian (Serravallian) paleoenvironmental transition, calibrated by sequence stratigraphy (Eastern Danube Basin). - Geologica Carpathica 71, 291-313. https://doi.org/10.31577/geolcarp.71.4.1

NosZKY, J. 1923: A Cserháttól északra levő terület földtani viszonyai. - A Magyar Királyi Földtani Intézet Évi Jelentése 1917-19-ról, Budapest, 48-60.

NoszKy, J. ID., Herrmann M. \& Nemesné VARGA S. 1952: A kelet-nógrádi andezitek. - Földtani Közlöny 82, 8-36.

Orton, G. J. 1996: Volcanic environments. - In: ReAding, H. G. (ed.): Sedimentary Environments: Processes, Facies and Stratigraphy. Blackwell Science, Oxford, 485-567.

PÉCSKAY Z. 2012: A K/Ar kormeghatározási módszer alkalmazása harmadidőszaki vulkáni területek geokronológiai kutatásában. Doctoral thesis of the Hungarian Academy of Sciences, MTA Atomki, 238 p. http://real-d.mtak.hu/514/

PlašIENKA, D. 2018. Continuity and episodicity in the early Alpine tectonic evolution of the Western Carpathians: How large-scale processes are expressed by the orogenic architecture and rock record data. - Tectonics 37, 2029-2079. https://doi.org/ 10.1029/2017TC004779

Prakfalvi P. 1996: A nógrádszakáli csevice kutatástörténete és földtana. - MSzG Salgótarjani Kirendeltség, Salgótarjan, 1-34.

PRAKFALVI P. 2012: A nógrádszakáli fatörzslenyomat-barlangok, kutatástörténete, földtana és genetikája. - Polar Studio, 22 p.

Reid, I. \& Frostick, L. E. 1994: Fluvial sediment transport and deposition. - In: Pye, K. (ed.): Sediment Transport and Deposition Processes. Blackwell Scientific Publication, Oxford, 89-144.

Rust, B. R. \& Koster, E. H. 1984: Coarse Alluvial Deposits. - In: WAlKer, R. G. (ed.): Facies Models. Geosience Canada, Reprint Series 1, 53-70.

Rust, B. R. 1972: Structures and process in a braided river. - Sedimentology 18, 221-245. https://doi.org/10.1111/j.1365-3091.1972.tb00013.x

Rust, B. R. 1978: Depositional models for braided alluvium. - In: Miall, A. D. (ed.): Fluvial Sedimentology. Memoir of the Geological Survey of Canada 5, 605-626.

ŠArinová, K., Rybár, S., HalásovÁ, E., HudáčKová, N., JAMrich, M., Kováčová, M. \& ŠuJAn, M. 2018: Integrated biostratigraphical, sedimentological and provenance analyses with implications lithostratigraphic ranking: the Miocene Komjatice Depression of the Danube Basin. - Geologica Carpathica 69, 382-409. https://doi.org/10.1515/geoca-2018-0023

Sambrook Smith, G. H., Best, J. L. Bristow, C. S. \& Petts, G. 2006: Braided rivers: where have we come in 10 years? Progress and future needs. - In: SAmbrook Smith, G. H., Best, J. L., Bristow, C. S. \& Petts, G. E. (eds): Braided Rivers: Process, Deposits, Ecology and Management. Special Publication of the International Association of Sedimentologists 36, 1-10. https://doi.org/10.1002/ 9781444304374.ch1

SCHLESINGER, G. 1922: Die Mastodonten der Budapester Sammlungen: Untersuchungen über Morphologie, Phylogenie, Ethologie und Stratigraphie europäischer Mastodonten. - Geologica Hungarica 2/1, 1-284.

SмITH, N. D. 1974: Sedimentology and bar formation in the upper Kicking Horse River, a braided outwash stream. - Journal of Geology 82, 205-223. https://doi.org/10.1086/627959

STEEL, R. J \& Thompson, D. B. 1983: Structures and textures in Triassic braided stream conglomerates ("Bunter" Pebble Beds) in the Sheiwood Sandstone Group, North Staffordshire, England. - Sedimentology 30, 341-367. https://doi.org/10.1111/j.1365-3091.1983. tb00677.x

Šujan, M., Rybár, S., KovÁč, M., Bielik, M., Majcin, D., MinÁr, J., Plašıenka, D., NovÁková, P. \& KotulovÁ, J. 2021: The polyphase rifting and inversion of the Danube Basin revised. - Global and Planetary Change 196, p. 103375. https://doi.org/10.1016/ j.gloplacha.2020.103375

TuBA L. 1985: Földtani térképezés és szedimentológiai vizsgálatok a nógrádszakáli Párizs-patak völgyében és környékén. - MSc dissertation, ELTE TTK Földtani Tanszék, Budapest, 1-113.

VARGA L. 1994: A magyarországi neogén orrszarvú-félék rendszertani és rétegtani értékelése. - MSc dissertation, ELTE TTK Őslénytani Tanszék, Budapest, 1-74.

VASS, D. 2002: Lithostratigraphy of Western Carpathians: Neogene and Buda Paleogene. - Státny geologický ústav Dionýza Stúra.

VAss, D., MiličKa, J., PereszlénYI, M. \& EleČKo, M. 2005: Lower Miocene coal measures buried by the Krupinská planina Plateau volcanics (southern Slovakia). - Bulletin of Geosciences 80, 105-112.

VENTRA, D. \& ClARKe, L. E. 2018: Geology and geomorphology of alluvial and fluvial fans: current progress and research perspectives. - Geological Society, London, Special Publications 440, 1-21. https://doi.org/10.1144/SP440.16

Venczel, M. \& Hír, J. 2015: Lissamphibians and squamate reptiles from the early middle Miocene of Litke, Northern Hungary. Geobios 48, 491-504. https://doi.org/10.1016/j.geobios.2015.09.001

Zelenka, T., Balázs, E., Balogh, K., Kiss, J., KozÁK, M., Nemesi, L., Pécskay, Z., PÜspöKi, Z., Ravasz, Cs., SzÉKy-Fux, V. \& ÚJfalussy, A. 2004: Buried Neogene volcanic structures in Hungary. - Acta Geologica Hungarica 47, 177-219. https://doi.org/10.1556/ ageol.47.2004.2-3.6

ZelenkA T. 2010: A Mátra hegység paleogén és neogén vulkanizmusa. - In: BARÁz Cs.,DudÁs Gy., Holló S., SzUROMi L. \& VoJTKó A. (szerk.): A Mátrai Tájvédelmi Körzet Heves és Nógrád határán. Bükki Nemzeti Park, Eger 27-38.

Kézirat beérkezett: 29/01/2021 